\title{
The Evaluation of Clinical and Cost Outcomes Associated with Earlier Initiation of Insulin in Patients with Type 2 Diabetes Mellitus
}

\author{
Harry J. Smolen, MS; Daniel R. Murphy, MS; James C. Gahn, BS; \\ Xueting Yu, PhD; and Bradley H. Curtis, DDS, MPH, PhD
}

\begin{abstract}
BACKGROUND: The treatment for patients with type 2 diabetes mellitus (T2DM) follows a stepwise progression. As a treatment loses its effectiveness, it is typically replaced with a more complex and frequently more costly treatment. Eventually this progression leads to the use of basal insulin typically with concomitant treatments (e.g., metformin, a GLP-1 RA [glucagon-like peptide-1 receptor agonist], a TZD [thiazolidinedione] or a DPP-4i [dipeptidyl peptidase 4 inhibitor]) and, ultimately, to basalbolus insulin in some forms. As the cost of oral antidiabetics (OADs) and noninsulin injectables have approached, and in some cases exceeded, the cost of insulin, we reexamined the placement of insulin in T2DM treatment progression. Our hypothesis was that earlier use of insulin produces clinical and cost benefits due to its superior efficacy and treatment scalability at an acceptable cost when considered over a 5-year period.
\end{abstract}

OBJECTIVES: To (a) estimate clinical and payer cost outcomes of initiating insulin treatment for patients with T2DM earlier in their treatment progression and (b) estimate clinical and payer cost outcomes resulting from delays in escalating treatment for T2DM when indicated by patient hemoglobin A1c levels.

METHODS: We developed a Monte Carlo microsimulation model to estimate patients reaching target A1c, diabetes-related complications, mortality, and associated costs under various treatment strategies for newly diagnosed patients with T2DM. Treatment efficacies were modeled from results of randomized clinical trials, including the time and rate of A1c drift. A typical treatment progression was selected based on the American Diabetes Association and the European Association for the Study of Diabetes guidelines as the standard of care (SOC). Two treatment approaches were evaluated: two-stage insulin (basal plus antidiabetics followed by biphasic plus metformin) and single-stage insulin (biphasic plus metformin). For each approach, we analyzed multiple strategies. For each analysis, treatment steps were sequentially and cumulatively removed from the SOC until only the insulin steps remained. Delays in escalating treatment were evaluated by increasing the minimum time on a treatment within each strategy. The analysis time frame was 5 years.

RESULTS: Relative to SOC, the two-stage insulin approach resulted in $0.10 \%$ to $1.79 \%$ more patients achieving target A1c $(<7.0 \%)$, at incremental costs of $\$ 95$ to $\$ 3,267$. (The ranges are due to the different strategies within the approach.) With the single-stage approach, $0.50 \%$ to $2.63 \%$ more patients achieved the target A1c compared with SOC at an incremental cost of $-\$ 1,642$ to $\$ 1,177$. Major diabetes-related complications were reduced by $0.38 \%$ to $17.46 \%$ using the two-stage approach and $0.72 \%$ to $25.92 \%$ using the single-stage approach. Severe hypoglycemia increased by $17.97 \%$ to $60.43 \%$ using the two-stage approach and $6.44 \%$ to $68.87 \%$ using the single-stage approach.
In the base case scenario, the minimum time on a specific treatment was 3 months. When the minimum time on each treatment was increased to 12 months (i.e., delayed), patients reaching A1c targets were reduced by $57 \%$, complications increased by $13 \%$ to $76 \%$, and mortality increased by $8 \%$ over 5 years when compared with the base case for the SOC. However, severe hypoglycemic events were reduced by $83 \%$.

CONCLUSIONS: As insulin was advanced earlier in therapy in the two-stage and single-stage approaches, patients reaching their A1c targets increased, severe hypoglycemic events increased, and diabetes-related complications and mortality decreased. Cost savings were estimated for 3 (of 4) strategies in the single-stage approach.

Delays in treatment escalation substantially reduced patients reaching target A1c levels and increased the occurrence of major nonhypoglycemic diabetic complications. With the exception of substantial increases in severe hypoglycemic events, earlier use of insulin mitigates the clinical consequences of these delays.

J Manag Care Pharm. 2014;20(9):968-84

Copyright $\odot 2014$, Academy of Managed Care Pharmacy. All rights reserved.

\section{What is already known about this subject}

American Diabetes Association (ADA) and European Association for the Study of Diabetes (EASD) guidelines on treatment of type 2 diabetes mellitus (T2DM) follow a stepwise progression that escalates treatment according to the hemoglobin Alc levels.

Oral antidiabetics and noninsulin injectable treatments, such as metformin, GLP-1 RAs, and DPP-4is, are subject to eventual loss of effectiveness that is known as Alc drift.

Research shows that the average time from the initiation of T2DM treatment to the initiation of insulin therapy is approximately 8 years, long after indicated by Alc levels.

\section{What this study adds}

Using the ADA and EASD treatment guidelines, this study created a Monte Carlo simulation model to estimate the clinical and cost outcomes of patients with T2DM over a 5-year period.

When compared with current real-world practices, earlier initiation of insulin increased the number of patients reaching Alc targets, decreased diabetic complications and mortality, but increased hypoglycemic events. In some cases, the earlier initiation of insulin was cost saving.

Delays in treatment escalation substantially increase diabetic complications and mortality. 


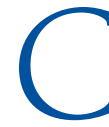
urrent treatment guidelines from the American Diabetes Association (ADA) and the European Association for the Study of Diabetes (EASD) ${ }^{1}$ focus on achieving and maintaining tight control of hemoglobin Alc for patients with type 2 diabetes mellitus (T2DM). Numerous studies have established that reductions in Alc levels decrease both macro- and microvascular complications..$^{2-4}$

The ADA-EASD treatment guidelines follow a stepwise additive progression, based on changes to patient Alc levels over 3-month intervals. ${ }^{1}$ Typically, the first step is metformin; the second step is metformin + sulfonylurea; and the third step adds an oral therapy (a dipeptidyl peptidase 4 inhibitor [DPP-4i] or a thiazolidinedione [TZD]) or a noninsulin injectable (glucagon-like peptide-1 receptor agonist [GLP-1 RA]). When the third step fails to achieve or maintain the desired Alc level, the fourth step adds basal insulin and removes sulfonylurea. Fourth-step failure leads to step 5, which is metformin + basal + prandial (bolus) insulin. ${ }^{1}$

Oral antidiabetics (OADs) and noninsulin injectables, although initially efficacious, are not a durable solution for most patients. Multiple studies ${ }^{5-8}$ show a pattern of efficacy for OADs and noninsulin injectables characterized by the following: (a) an initial precipitous drop in Alc postinitiation; (b) a brief plateau in Alc, followed by (c) a gradual increase in Alc (referred to as Alc drift). Alc drift occurs because of loss of $\beta$ cell function (see Kahn et al. 2006 ${ }^{9}$ ) or insulin sensitivity. This Alc drift exposes the patient to elevated risks of macrovascular and microvascular complications.

The Alc drift that occurs with an appropriately titrated dosage of basal insulin + OADs or noninsulin injectables is typically less than with OADs and/or noninsulin injectables (see Appendix A). With appropriate monitoring and titration, basal+bolus insulin therapy should be subject to even less or no Alc drift so that the risk of complications may be ameliorated.

The primary objective of this study was to estimate the clinical and cost outcomes of initiating insulin treatment for T2DM patients earlier in their treatment progression. Our secondary objective was to determine how HbAlc drift combined with delays in treatment escalation affect clinical outcomes and payer costs. The hypothesis was that earlier use of insulin may produce benefits due to its efficacy and treatment scalability at an acceptable cost when considered over a 5-year period.

\section{Methods}

\section{Model Overview}

We developed a Monte Carlo microsimulation model to estimate clinical and cost outcomes for patients newly diagnosed with T2DM under various treatment strategies. The simulated population was a heterogeneous cohort of patients in the United States with respect to initial age (>aged 20 years), gender, ethnicity, and diabetes complication history. Model outputs included the number of patients reaching target Alc, major T2DM complications, mortality, and costs (total, pharmacy, and direct medical). The model time frame was 5 years (60 months) with a 1-month fixed time cycle length. Model input data and sources are listed in Appendix A.

An overview of the model structure and flow is presented in Figure 1. First, the model creates an individual simulated patient and assigns baseline demographic and clinical characteristics. Next, the model determines whether in the current model cycle the patient experiences a major T2DM complication event. These events are severe hypoglycemia, myocardial infarction (MI), stroke, blindness, lower extremity amputation (LEA), and end-stage renal disease (ESRD). The event determination involves comorbidity submodels for nephropathy, neuropathy, retinopathy, stroke, coronary heart disease (CHD), and hypoglycemia. The submodels were adapted from models originally developed by the CDC Diabetes Cost-effectiveness Group. ${ }^{10}$ The model then determines whether the patient dies in the current cycle. The probability that a patient dies in a particular cycle is a function of the patient's comorbidity-related mortality and overall natural mortality. If the patient dies during a particular cycle, then the patient exits the model.

If the patient does not die during a particular cycle, the model checks to see if the model time frame has expired. If not, the patient's Alc level is updated. This is determined by the patient's Alc level from the previous cycle, the patient's current treatment, and whether the patient has achieved durable control of Alc. Durable control is defined as the ability to maintain an Alc level below the target (7\% for these analyses). The ADA-EASD guidelines recommend lowering Alc to $<7.0 \%$ in most patients. ${ }^{1}$ They note that more/less stringent Alc targets be considered in patients based on their disease duration, life expectancy, diabetes-related complications, and other factors.

Next, the model determines whether the patient's treatment within a strategy is updated (escalated). Patients not achieving durable Alc control are subject to Alc drift after a specific period of time on treatment (a treatment modifiable model input). Once a patient's Alc fails to decline or remain below the Alc target for a prescribed amount of time (treatment specific), the patient will advance to the next step in the treatment progression (e.g., from metformin to metformin + sulfonylurea). This completes the patient cycle.

During a model run, each of the patients were cloned $n$ times to correspond to $n$ treatment strategies being compared, i.e., identical patients were simulated for each treatment strategy. Common random numbers were used with each cloned patient between treatment strategies to reduce extraneous sampling variation. ${ }^{11}$ 


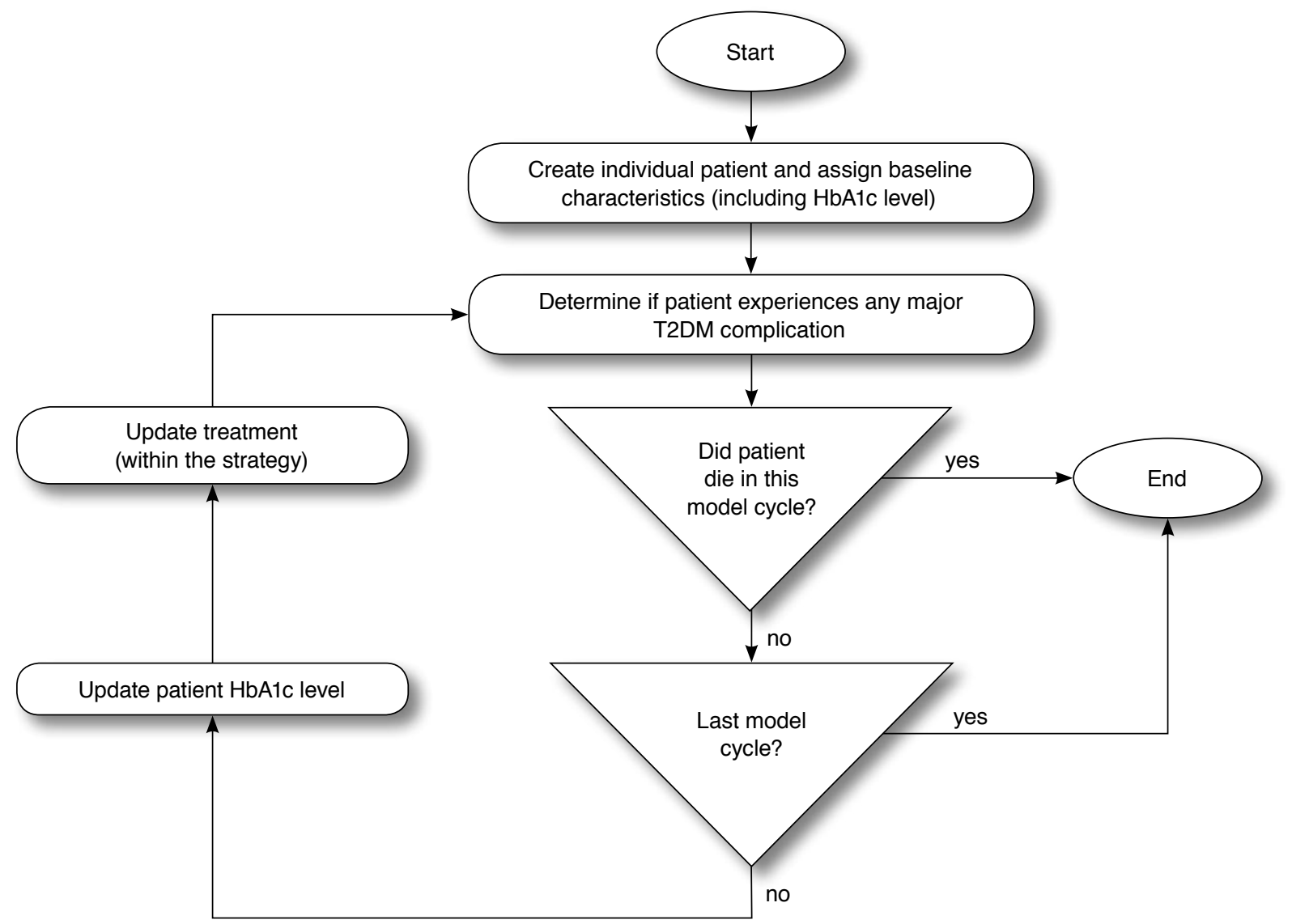

HbA1c=hemoglobin A1c; T2DM = type 2 diabetes mellitus.

\section{Treatment Strategies}

In the model, we defined the T2DM standard of care (SOC) as the treatment progression presented in the first column in Table 1. Consistent with the ADA-EASD guidelines, ${ }^{1}$ we defined 2 insulin-related steps within the SOC: the use of basal insulin with metformin plus DPP-4i, and the use of biphasic insulin with metformin. Alternatively, we could have chosen basal-bolus as the terminal insulin treatment. Biphasic insulin efficacy data was sourced from the 2007 Holman et al. study, which was a randomized, large $(\mathrm{N}=708)$, and relatively long-term (1 year) study. ${ }^{12}$ Furthermore, multiple studies have shown biphasic insulin to be as efficacious as basal-bolus insulin in reducing Alc in T2DM patients. ${ }^{13-16}$

Our selection of the SOC treatment pattern was taken from the ADA-EASD and American Association of Clinical Endocrinologists-American College of Endocrinology (AACEACE) guidelines. ${ }^{1,17}$ It was intended to be representative of, rather than inclusive of, all possible T2DM treatment patterns referenced in the guidelines. Other treatment patterns using GLP-1s or TZDs, rather than DPP-4s, could have been evaluated as well. We chose DPP-4s because they represent the largest noninsulin treatment in sales volume for T2DM. The goal for this analysis was to base the SOC treatment strategy on a typically used pattern so the implications of earlier insulin usage could be examined in the most general context possible.

The treatment strategies simulated in the model are variations of the 5-step escalation pattern of the SOC. Two treatment strategy approaches were used (see Table 1). In Approach 1, steps 3, 2, and 1 were sequentially and cumulatively removed from the SOC, effectively moving the later (insulin) steps earlier in treatment pattern, that is, steps 1,2,3,4,5 (SOC); 1,2,4,5; $1,4,5$; and 4,5 . This is referred to as the two-stage insulin approach (steps 4 and 5). In Approach 2, step 4 (basal insulin) is excluded from all the strategies, that is, steps $1,2,3,5 ; 1,2,5$; 1,5 ; and 5 . The second approach is referred to as the singlestage insulin approach (step 5). 
TABLE 1 Modeled Comparator Approaches-Approach 1: Two-Stage Insulin and Approach 2: Single-Stage Insulin

\begin{tabular}{|c|c|c|}
\hline Standard of Care & Approach 1: Two-Stage Insulina & Approach 2: Single-Stage Insulina \\
\hline \multirow{4}{*}{$\begin{array}{l}\text { 1. } \text { metformin } \\
\text { 2. metformin }+ \text { sulfonylurea } \\
\text { 3. metformin }+ \text { sulfonylurea }+ \text { DPP }-4 i \\
\text { 4. metformin }+ \text { DPP- } 4 i+\text { basal insulin } \\
\text { 5. metformin + biphasic insulin }\end{array}$} & $\begin{array}{l}\text { 1. } \text { metformin } \\
\text { 2. metformin + sulfonylurea } \\
\text { 4. metformin + DPP-4i+basal insulin } \\
\text { 5. metformin + biphasic insulin }\end{array}$ & $\begin{array}{l}\text { 1. metformin } \\
\text { 2. metformin + sulfonylurea } \\
\text { 3. metformin + sulfonylurea + DPP-4i } \\
\text { 5. metformin + biphasic insulin }\end{array}$ \\
\hline & $\begin{array}{l}\text { 1. } \text { metformin } \\
\text { 4. metformin + DPP-4i+basal insulin } \\
\text { 5. metformin + biphasic insulin }\end{array}$ & $\begin{array}{l}\text { 1. } \text { metformin } \\
\text { 2. metformin + sulfonylurea } \\
\text { 5. metformin + biphasic insulin }\end{array}$ \\
\hline & \multirow{2}{*}{$\begin{array}{l}\text { 4. } \text { metformin }+ \text { DPP- } 4 i+\text { basal insulin } \\
\text { 5. metformin + biphasic insulin }\end{array}$} & $\begin{array}{l}\text { 1. metformin } \\
\text { 5. metformin + biphasic insulin }\end{array}$ \\
\hline & & 5. metformin + biphasic insulin \\
\hline
\end{tabular}

aFor Approach 1 and Approach 2, the numbering of the steps within a specific strategy is consistent with the numbering for the standard of care. $D P P-4 i=$ dipeptidyl peptidase 4 inhibitor

\section{Sources of Model Parameters}

Demographic and Clinical. The model estimated the T2DM population by age (20-39, 40-64, and 65 or greater); race (nonHispanic white, non-Hispanic black, Hispanic, and other); and gender. The general population demographic data came from the 2008 Current Population Survey. ${ }^{18}$ T2DM prevalence data for the age, race, and gender groups came from National Health and Nutrition Examination Survey Data (NHANES) ${ }^{19}$ and Danaei et al. (2009). ${ }^{20}$ The primary source for major T2DM nonhypoglycemia complications was Valentine et al. (2006). ${ }^{21}$ Data for estimating severe hypoglycemia came from Curkendall et al. (2011).22

Diabetic Comorbidity Submodels. The submodels for the T2DM comorbidities came from the CDC Diabetes Costeffectiveness Group. ${ }^{10}$ The submodels for CHD and stroke were adapted using transition probabilities from the United Kingdom Prospective Diabetes Study. ${ }^{23}$ Relative risk reductions resulting from comorbidity treatments were based on data for nephropathy, ${ }^{2,24}$ neuropathy and retinopathy, ${ }^{2}$ stroke, ${ }^{2,25}$ and coronary heart disease. ${ }^{2,25-27}$

Treatment. T2DM treatment efficacies used in the model were obtained from published randomized clinical trial data (see Appendix A). After initiation of a particular treatment (e.g., metformin +sulfonylurea), we split T2DM treatment efficacy into 2 segments. In the first segment, the Alc level decreases at a given rate for a specified time. In the second segment, the treatment becomes less efficacious and the patient's Alc level drifts upward. For each treatment, the model has distinct inputs for efficacy per month, months until Alc drift onset, and Alc drift per month.

The model allows the user to specify a minimum number of months on each treatment used. This represents the time a physician will allow a patient to remain on a specific treatment before considering an escalation. We used a minimum time on each treatment of 3 months in the base case analysis from the ADA-EASD guidelines (Inzucchi et al. 2012). ${ }^{1}$
Treatment adherence by ethnicity for T2DM was sourced from Suh et al. (2010) $)^{28}$ and Rajagopalan et al. (2003). ${ }^{29}$ Additionally, the first time a patient's Alc reached the defined target, the model probabilistically determined whether they will remain at target, that is, achieve durable control. This determination is based on probabilities by ethnicity from Suh et al. ${ }^{28}$

Associated with each treatment are an annual percentage of severe hypoglycemic events. Incidence and cost data for severe hypoglycemia events was sourced from Curkendall et al. ${ }^{22}$ These events were identified by International Classification of Diseases, Ninth Revision, Clinical Modification codes from an analysis of commercial and Medicare databases. The severe hypoglycemia event costs used in the model were the weighted average of event-related costs for inpatient, emergency room plus inpatient, emergency room, and outpatient services.

Costs related to nonhypoglycemic complications (e.g., nephropathy, neuropathy, and retinopathy) were based on direct medical costs using a model from Brandle et al. (2003)..$^{30}$ The Brandle model uses a base cost and multipliers associated with identified patient characteristics. Annual direct medical costs for major events such as MI, stroke, and LEA were also taken from Brandle et al. ${ }^{30}$ Annual drug costs were obtained from the Redbook $^{31}$ for each treatment. Where applicable, cost data were inflated to 2013 values. ${ }^{32}$ Costs for physician visits were not included in the model. These costs would have been equal for both SOC and comparator treatments and thus would not have affected the incremental costs that were the focus of our analyses.

\section{Results}

\section{Base Case}

Table 2 and Table 3 present model clinical and cost outcome results. The results are presented as differences between SOC (steps 1,2,3,4,5) and each comparator strategy for simulated patients. The comparator strategies are grouped by Approach 1 (two-stage insulin, steps 4,5) and Approach 2 (single-stage insulin, step 5). 
FIGURE 2 Alc Levels of SOC and Strategies in Approach 1 and Strategies in Approach 2 over Time

\section{A. Approach 1: Two-Stage Insulin}

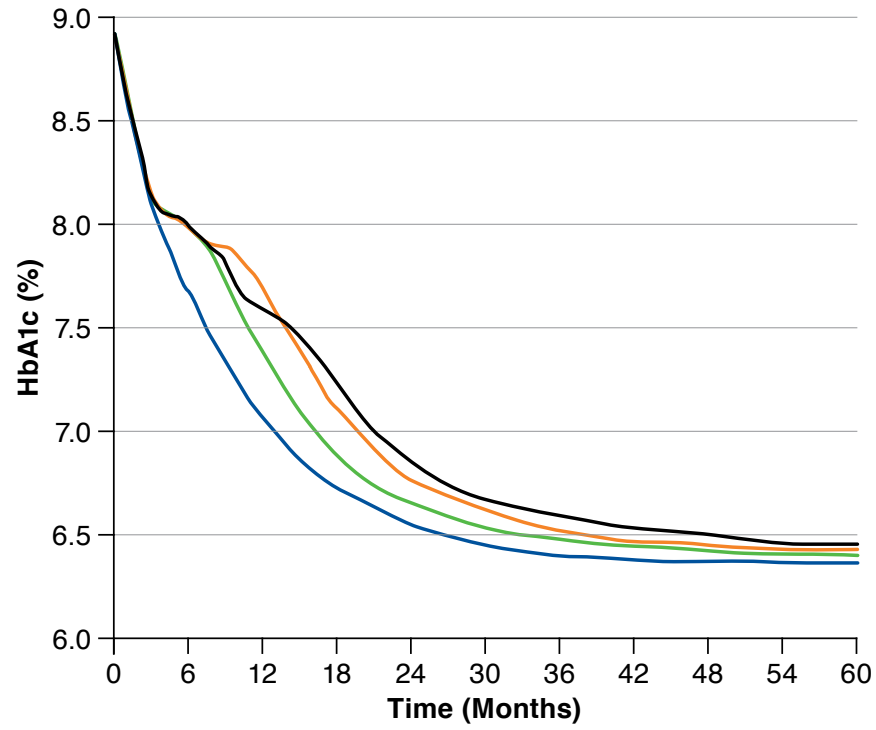

B. Approach 2: Single-Stage Insulin

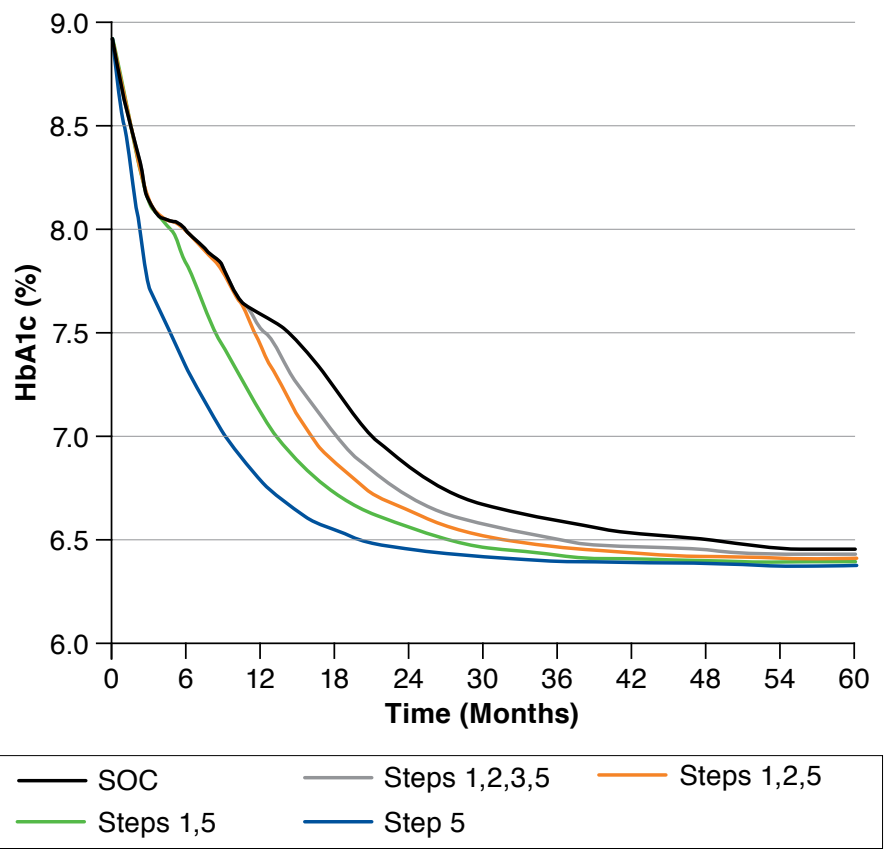

HbAlc = hemoglobin Alc; SOC = standard of care.

For Approach 1, relative to SOC, moving the two-stage insulin (steps 4,5) earlier in the treatment progression increased pharmacy and total costs (Table 3). It also increased severe hypoglycemic events (Table 2). However, it resulted in additional patients reaching target Alc, reductions in all major T2DM complications (i.e., MIs, strokes, blindness, LEAs, ESRD), and reductions in all-cause deaths. The incremental total cost per patient (\%) was $\$ 95(0.26 \%)$ for strategy I (steps $1,2,4,5) ; \$ 1,164$ (3.32\%) for strategy II (steps $1,4,5$ ); and $\$ 3,267$ (9.05\%) for strategy III (steps 4,5).

For Approach 2, step 4 (metformin + DPP-4i+basal insulin) was removed from all 4 strategies and the single-stage insulin (step 5) was moved progressively earlier in treatment. As steps 3,2 , and 1 are incrementally removed from the strategies, relative to SOC, there was an increase in the number of patients reaching target Alc, major T2DM complications prevented, and all-cause deaths prevented. Conversely, severe hypoglycemic events increased.

In Approach 2, relative to SOC, there were negative incremental total costs per patient (\%), that is, cost savings-for strategies IV (steps 1,2,3,5); V (steps 1,2,5); and VI (steps 1,5) of $-\$ 1,642(-4.55 \%),-\$ 1,602(-4.44 \%)$, and $-\$ 612(-1.70 \%)$, respectively. These savings were the result of lower pharmacy costs and reductions in nonhypoglycemic major T2DM com- plications. These reductions in complications occurred due to lower Alc levels resulting from initiating biphasic insulin (step 5) earlier in the treatment progression. Nevertheless, when the strategy consisted of only step 5 (metformin + biphasic insulin), there was a cost increase of $\$ 1,177$ (3.26\%). This was due to the increased number of severe hypoglycemic events and the use of the more expensive biphasic insulin at the start of treatment.

Recall that Approach 1 utilized two-stage insulin (steps 4 and 5) and Approach 2 utilized single-stage insulin (step 5). Accordingly, Approach l's strategies I, II, and III are analogous to Approach 2's strategies V, VI, and VII, respectively (see Table 1 and Table 2). Approach 2's strategy IV is not analogous to any strategy in Approach 1. When comparing analogous strategies between Approach 1 and Approach 2, Approach 2 is superior in terms of patients reaching target Alc, nonhypoglycemic major T2DM complications prevented, and all-cause deaths prevented. Conversely, in each analogous case, Approach 2 is inferior in terms of additional severe hypoglycemic events.

Figure 2 displays the Alc curves versus time comparing the strategies within Approach 1 (Figure 2A, using two-stage insulin) and Approach 2 (Figure 2B, using single-stage insulin) to the SOC strategy. The horizontal axis represents the model time frame (60 months). Whether Approach 1 or Approach 2 is employed, the earlier insulin is initiated in the treatment 
TABLE 2 Clinical Outcome Model Results: Patients Reaching Target Alc, Major T2DM Complications, and Mortality ${ }^{\mathrm{a}}$

\begin{tabular}{|c|c|c|c|c|c|c|c|c|c|}
\hline \multicolumn{2}{|c|}{ Comparator Strategy } & $\begin{array}{c}\text { Patients } \\
\text { Reaching } \\
\text { Target Alc } \\
\end{array}$ & \begin{tabular}{|c|}
$\begin{array}{c}\text { Severe } \\
\text { Hypoglycemic } \\
\text { Events }\end{array}$ \\
\end{tabular} & MIs & Strokes & Blindness & LEAs & ESRD & $\begin{array}{l}\text { All-Cause } \\
\text { Deaths }\end{array}$ \\
\hline & Standard of Care & \multicolumn{8}{|c|}{ Base Case } \\
\hline \multirow[t]{2}{*}{0.} & $\begin{array}{l}\text { 1. } \text { metformin } \\
\text { 2. metformin + sulfonylurea } \\
\text { 3. metformin + sulfonylurea + DPP- } 4 i \\
\text { 4. metformin + DPP- } 4 \text { + basal insulin } \\
\text { 5. metformin + biphasic insulin }\end{array}$ & 93,905 & 21,570 & 7,154 & 2,644 & 3,547 & 3,900 & 88 & 21,407 \\
\hline & Approach 1: Two-Stage Insulin & \multicolumn{8}{|c|}{ Incremental to Base Case } \\
\hline I. & $\begin{array}{l}\text { 1. metformin } \\
\text { 2. metformin + sulfonylurea } \\
\text { 4. metformin + DPP- } 4 i+\text { basal insulin } \\
\text { 5. metformin + biphasic insulin }\end{array}$ & $\begin{array}{c}93 \\
(0.10 \%)\end{array}$ & $\begin{array}{c}3,876 \\
(17.97 \%)\end{array}$ & $\begin{array}{c}-30 \\
(-0.42 \%)\end{array}$ & $\begin{array}{c}-10 \\
(-0.38 \%)\end{array}$ & $\begin{array}{c}-30 \\
(-0.85 \%)\end{array}$ & $\begin{array}{c}-32 \\
(-0.82 \%)\end{array}$ & $\begin{array}{c}-1 \\
(-1.14 \%)\end{array}$ & $\begin{array}{c}-20 \\
(-0.09 \%)\end{array}$ \\
\hline II. & $\begin{array}{l}\text { 1. metformin } \\
\text { 4. metformin + DPP- } 4 \mathrm{i}+\text { basal insulin } \\
\text { 5. metformin + biphasic insulin }\end{array}$ & $\begin{array}{c}788 \\
(0.84 \%)\end{array}$ & $\begin{array}{c}6,976 \\
(32.34 \%)\end{array}$ & $\begin{array}{c}-101 \\
(-1.41 \%)\end{array}$ & $\begin{array}{c}-29 \\
(-1.10 \%)\end{array}$ & $\begin{array}{c}-190 \\
(-5.36 \%)\end{array}$ & $\begin{array}{c}-310 \\
(-7.95 \%)\end{array}$ & $\begin{array}{c}-5 \\
(-5.68 \%)\end{array}$ & $\begin{array}{c}-66 \\
(-0.31 \%)\end{array}$ \\
\hline \multirow[t]{2}{*}{ III. } & $\begin{array}{l}\text { 4. metformin + DPP- } 4 i+\text { basal insulin } \\
\text { 5. metformin + biphasic insulin }\end{array}$ & $\begin{array}{c}1,677 \\
(1.79 \%)\end{array}$ & $\begin{array}{l}13,034 \\
(60.43 \%) \\
\end{array}$ & $\begin{array}{c}-190 \\
(-2.66 \%) \\
\end{array}$ & $\begin{array}{c}-54 \\
(-2.04 \%) \\
\end{array}$ & $\begin{array}{c}-413 \\
(-11.64 \%) \\
\end{array}$ & $\begin{array}{c}-681 \\
(-17.46 \%) \\
\end{array}$ & $\begin{array}{c}-12 \\
(-13.64 \%) \\
\end{array}$ & $\begin{array}{c}-128 \\
(-0.60 \%) \\
\end{array}$ \\
\hline & Approach 2: Single-Stage Insulin & \multicolumn{8}{|c|}{ Incremental to Base Case } \\
\hline IV. & $\begin{array}{l}\text { 1. } \text { metformin } \\
\text { 2. metformin + sulfonylurea } \\
\text { 3. metformin + sulfonylurea + DPP- } 4 \mathrm{i} \\
\text { 5. metformin + biphasic insulin }\end{array}$ & $\begin{array}{c}468 \\
(0.50 \%)\end{array}$ & $\begin{array}{l}1,390 \\
(6.44 \%)\end{array}$ & $\begin{array}{c}-62 \\
(-0.87 \%)\end{array}$ & $\begin{array}{c}-19 \\
(-0.72 \%)\end{array}$ & $\begin{array}{c}-113 \\
(-3.19 \%)\end{array}$ & $\begin{array}{c}-196 \\
(-5.03 \%)\end{array}$ & $\begin{array}{c}-4 \\
(-4.55 \%)\end{array}$ & $\begin{array}{c}-43 \\
(-0.20 \%)\end{array}$ \\
\hline $\mathrm{V}$. & $\begin{array}{l}\text { 1. metformin } \\
\text { 2. metformin + sulfonylurea } \\
\text { 5. metformin + biphasic insulin }\end{array}$ & $\begin{array}{c}721 \\
(0.77 \%)\end{array}$ & $\begin{array}{c}5,237 \\
(24.28 \%)\end{array}$ & $\begin{array}{c}-97 \\
(-1.36 \%)\end{array}$ & $\begin{array}{c}-33 \\
(-1.25 \%)\end{array}$ & $\begin{array}{c}-187 \\
(-5.27 \%)\end{array}$ & $\begin{array}{c}-290 \\
(-7.44 \%)\end{array}$ & $\begin{array}{c}-4 \\
(-4.55 \%)\end{array}$ & $\begin{array}{c}-69 \\
(-0.32 \%)\end{array}$ \\
\hline VI. & $\begin{array}{l}\text { 1. metformin } \\
\text { 5. metformin + biphasic insulin }\end{array}$ & $\begin{array}{c}1,486 \\
(1.58 \%) \\
\end{array}$ & $\begin{array}{c}8,340 \\
(38.66 \%) \\
\end{array}$ & $\begin{array}{c}-178 \\
(-2.49 \%) \\
\end{array}$ & $\begin{array}{c}-46 \\
(-1.74 \%) \\
\end{array}$ & $\begin{array}{c}-344 \\
(-9.70 \%) \\
\end{array}$ & $\begin{array}{c}-584 \\
(-14.97 \%) \\
\end{array}$ & $\begin{array}{c}-11 \\
(-12.50 \%) \\
\end{array}$ & $\begin{array}{c}-119 \\
(-0.56 \%) \\
\end{array}$ \\
\hline VII. & 5. metformin + biphasic insulin & $\begin{array}{c}2,470 \\
(2.63 \%)\end{array}$ & $\begin{array}{c}14,856 \\
(68.87 \%)\end{array}$ & $\begin{array}{c}-283 \\
(-3.96 \%)\end{array}$ & $\begin{array}{c}-76 \\
(-2.87 \%)\end{array}$ & $\begin{array}{c}-622 \\
(-17.54 \%)\end{array}$ & $\begin{array}{c}-1,011 \\
(-25.92 \%)\end{array}$ & $\begin{array}{c}-19 \\
(-21.59 \%)\end{array}$ & $\begin{array}{c}-194 \\
(-0.91 \%)\end{array}$ \\
\hline
\end{tabular}

a Results presented as difference between SOC (steps 1,2,3,4,5) and each comparator strategy per 100,000 patients over a 5-year period. The percentages given represent the relative increase/decrease from the associated base case value.

Alc =hemoglobin Alc; DPP-4i=dipeptidyl peptidase 4 inhibitor; $E S R D=$ end-stage renal disease; $L E A=$ lower extremity amputation; $M I=m y o c a r d i a l$ infarction;

SOC $=$ standard of care; T2DM = type 2 diabetes mellitus.

progression, the quicker a steady-state Alc level is achieved at or below target. Reduction in time to target results in fewer nonhypoglycemic complications and reduced mortality (see Table 2).

\section{Effects of Delaying Treatment Escalation}

In the base case, we set a patient's minimum time on a particular treatment within a strategy to 3 months. In practice, however, for many patients with T2DM, the interval between treatment changes is substantially longer. ${ }^{33-36}$ To examine the effects of these longer intervals, we estimated clinical and cost outcomes associated with minimum time on a treatment of 6 and 12 months.

The associated clinical outcomes of this sensitivity analysis are presented in Table 4. These outcomes show that as the time interval between treatment escalations within a strategy increases, the estimated number of T2DM major complications, except severe hypoglycemic events, increases. These increases are the result of longer periods of Alc drift and subsequent lon- ger periods of recovery (from that drift) after the next treatment within a strategy is initiated.

As presented in Table 2 and Table 4, for the SOC treatment, the number of patients reaching the target Alc level is reduced by $57 \%$ with a minimum time on a treatment of 12 months versus 3 months. The complications associated with a 12-month minimum time on treatment also increased by $13 \%$ to $76 \%$ (depending on the complication). Severe hypoglycemic events, as expected, decreased substantially (83\%) due to higher Alc levels.

Using the SOC, the model estimated 7,154 MIs at 3 months and 8,333 MIs at 12 months, respectively, of minimum time on treatment. As an example using Approach 1 and strategy I (steps 1,2,4,5), the model estimated 7,124 MIs at 3 months and 7,994 MIs at 12 months. Using Approach 1 and strategy III (steps 4,5), the model estimated 6,964 MIs at 3 months and 7,150 at 12 months. As insulin is applied earlier in each respective approach and strategy, the effects of delays in treatment escalation are mitigated, with the exception of major hypoglycemic events. 
TABLE 3 Cost Outcome Model Results: Pharmacy Costs, Direct Medical Costs, and Total Costs ${ }^{\mathrm{a}}$

\begin{tabular}{|c|c|c|c|c|}
\hline \multicolumn{2}{|c|}{ Comparator Strategy } & Pharmacy Costs Per Patient & $\begin{array}{c}\text { Direct Medical Costs Per } \\
\text { Patient }\end{array}$ & Total Costs Per Patient \\
\hline & Standard of Care & \multicolumn{3}{|c|}{ Base Case } \\
\hline \multirow[t]{2}{*}{0 . } & $\begin{array}{l}\text { 1. } \text { metformin } \\
\text { 2. metformin + sulfonylurea } \\
\text { 3. metformin + sulfonylurea + DPP- } 4 i \\
\text { 4. metformin + DPP- } 4 \text { i + basal insulin } \\
\text { 5. metformin + biphasic insulin }\end{array}$ & $\$ 11,062$ & $\$ 25,028$ & $\$ 36,090$ \\
\hline & Approach 1: Two-Stage Insulin & \multicolumn{3}{|c|}{ Incremental to Base Case } \\
\hline I. & $\begin{array}{l}\text { 1. metformin } \\
\text { 2. metformin + sulfonylurea } \\
\text { 4. metformin + DPP-4i+basal insulin } \\
\text { 5. metformin + biphasic insulin }\end{array}$ & $\$ 89(0.80 \%)$ & $\$ 6(0.02 \%)$ & $\$ 95(0.26 \%)$ \\
\hline II. & $\begin{array}{l}\text { 1. metformin } \\
\text { 4. metformin + DPP- } 4 \mathrm{i}+\text { basal insulin } \\
\text { 5. metformin + biphasic insulin }\end{array}$ & $\$ 1,400(12.66 \%)$ & $-\$ 235(-0.94 \%)$ & $\$ 1,164(3.23 \%)$ \\
\hline \multirow[t]{2}{*}{$\overline{\text { III. }}$} & $\begin{array}{l}\text { 4. metformin + DPP- } 4 i+\text { basal insulin } \\
\text { 5. metformin + biphasic insulin }\end{array}$ & $\$ 3,782(34.19 \%)$ & $-\$ 515(-2.06 \%)$ & $\$ 3,267(9.05 \%)$ \\
\hline & Approach 2: Single-Stage Insulin & \multicolumn{3}{|c|}{ Incremental to Base Case } \\
\hline IV. & $\begin{array}{l}\text { 1. metformin } \\
\text { 2. metformin + sulfonylurea } \\
\text { 3. metformin + sulfonylurea + DPP- } 4 \text { i } \\
\text { 5. metformin + biphasic insulin }\end{array}$ & $-\$ 1,478(-13.36 \%)$ & $-\$ 165(-0.66 \%)$ & $-\$ 1,642(-4.55 \%)$ \\
\hline V. & $\begin{array}{l}\text { 1. metformin } \\
\text { 2. metformin + sulfonylurea } \\
\text { 5. metformin + biphasic insulin }\end{array}$ & $-\$ 1,385(-12.52 \%)$ & $-\$ 217(-0.87 \%)$ & $-\$ 1,602(-4.44 \%)$ \\
\hline VI. & $\begin{array}{l}\text { 1. metformin } \\
\text { 5. metformin + biphasic insulin }\end{array}$ & $-\$ 134(-1.21 \%)$ & $-\$ 478(-1.91 \%)$ & $-\$ 612(-1.70 \%)$ \\
\hline VII & 5. metformin + biphasic insulin & $\$ 1,996(18.04 \%)$ & $-\$ 819(-3.27 \%)$ & $\$ 1,177(3.26 \%)$ \\
\hline
\end{tabular}

a Results presented as difference between SOC (steps 1,2,3,4,5) and each comparator strategy per patient over a 5-year period. The percentages given represent the relative increase/decrease from the associated base case value.

DPP-4i= dipeptidyl peptidase 4 inhibitor; SOC= standard of care.

Figure 3 shows the plots of Alc versus time for both Approach 1 (two-stage insulin) and Approach 2 (single-stage insulin) as the minimum time on a treatment is extended to 6 and 12 months, respectively. Comparing these plots to those in Figure 2, note that the time required to reach target Alc $(7 \%)$ is substantially increased. When the minimum treatment duration of 3 months was used, the SOC reached the target Alc at approximately 22 months (Figure 2A). When the minimum time on a treatment of 6 and 12 months was simulated, the time to reach target for SOC increased to approximately 32 months and more than 60 months, respectively.

When the minimum time on treatment is set to 6 months, the escalation from metformin to metformin + sulfonylurea occurs at 6 months, and the escalation from metformin + sulfonylurea to metformin + sulfonylurea+DPP-4i occurs at 12 months (Figure 3A). The starting and ending mean Alc levels for metformin + sulfonylurea are $8.2 \%$ and $8.2 \%$, respectively. With the minimum time on treatment set to 12 months, the metformin + sulfonylurea treatment starts at 12 months and ends at 24 months with mean Alc levels at $8.4 \%$ and $8.9 \%$, respectively (Figure $3 \mathrm{C}$ ). In both cases, the effectiveness of the treatment is lost due to the failure to escalate treatment to the next step in a timely manner (i.e., 3 months), allowing Alc drift to continue.

In Approach 1, the steps 4,5 treatment strategy takes 14, 15, and 22 months to reach the target Alc with a minimum time on treatment of 3, 6, and 12 months, respectively. In Approach 2 , the treatment strategy step 5 takes 10 months to reach the target without regard to minimum time on treatment. Both strategies take substantially shorter time than SOC regardless of the delay of treatment escalation. As insulin is initiated earlier, the accumulated nonhypoglycemic complication risks associated with Alc drift in the SOC are reduced.

The cost outcomes estimated for the minimum time on treatment analyses are found in Appendix B. These cost outcomes follow the same general pattern. As delays in switching treatment increase, earlier use of insulin reduces T2DM complication costs because lengthy periods of Alc drift are eliminated (see Figure 3). These reductions offset the higher pharmacy costs of using insulin earlier in the treatment pattern and, in 11 of 14 cases, result in total cost savings. 
TABLE 4 For Minimum Step Treatment Duration of 6 and 12 Months, Clinical Outcome Model Results: Patients Reaching Target Alc, T2DM Complications, and Mortality over a 5-Year Period ${ }^{a}$

\begin{tabular}{|c|c|c|c|c|c|c|c|c|c|c|}
\hline \multicolumn{2}{|c|}{ Comparator Strategy } & $\begin{array}{l}\text { Minimum } \\
\text { Step } \\
\text { Treatment } \\
\text { Duration }\end{array}$ & $\begin{array}{c}\text { Patients } \\
\text { Reaching } \\
\text { Target Alc }\end{array}$ & \begin{tabular}{|c|} 
Severe \\
Hypoglycemic \\
Events
\end{tabular} & MIs & Strokes & Blindness & LEAs & ESRD & $\begin{array}{c}\text { All-Cause } \\
\text { Deaths }\end{array}$ \\
\hline & Standard of Care & \multicolumn{9}{|c|}{ Base Case } \\
\hline \multirow[t]{3}{*}{$\overline{0 .}$} & \multirow{2}{*}{$\begin{array}{l}\text { 1. metformin } \\
\text { 2. metformin + sulfonylurea } \\
\text { 3. metformin + sulfonylurea } \\
\text { +DPP-4i } \\
\text { 4. metformin + DPP- } 4 \mathrm{i}+\text { basal } \\
\text { insulin } \\
\text { 5. metformin + biphasic insulin }\end{array}$} & 6 months & 90,790 & 19,394 & 7,381 & 2,713 & 4,190 & 5,368 & 119 & 21,630 \\
\hline & & 12 months & 59,700 & 11,758 & 8,333 & 3,032 & 7,278 & 16,396 & 351 & 23,203 \\
\hline & Approach 1: Two-Stage Insulin & \multicolumn{9}{|c|}{ Incremental to Base Case } \\
\hline \multirow[t]{2}{*}{ I. } & \multirow{2}{*}{$\begin{array}{l}\text { 1. metformin } \\
\text { 2. metformin + sulfonylurea } \\
\text { 4. metformin + DPP-4i+basal } \\
\text { insulin } \\
\text { 5. metformin + biphasic insulin }\end{array}$} & 6 months & $\begin{array}{c}1,116 \\
(1.23 \%) \\
\end{array}$ & $\begin{array}{c}4,007 \\
(20.66 \%) \\
\end{array}$ & $\begin{array}{c}-82 \\
(-1.11 \%) \\
\end{array}$ & $\begin{array}{c}-30 \\
(-1.11 \%) \\
\end{array}$ & $\begin{array}{c}-190 \\
(-4.53 \%) \\
\end{array}$ & $\begin{array}{c}-438 \\
(-8.16 \%) \\
\end{array}$ & $\begin{array}{c}-12 \\
(-10.08 \%) \\
\end{array}$ & $\begin{array}{c}-76 \\
(-0.35 \%) \\
\end{array}$ \\
\hline & & 12 months & $\begin{array}{c}19,392 \\
(32.48 \%)\end{array}$ & $\begin{array}{c}5,410 \\
(46.01 \%)\end{array}$ & $\begin{array}{c}-339 \\
(-4.07 \%)\end{array}$ & $\begin{array}{c}-119 \\
(-3.92 \%)\end{array}$ & $\begin{array}{c}-1,092 \\
(-15.00 \%)\end{array}$ & $\begin{array}{c}-4,701 \\
(-28.67 \%)\end{array}$ & $\begin{array}{c}-103 \\
(-29.34 \%)\end{array}$ & $\begin{array}{c}-684 \\
(-2.95 \%)\end{array}$ \\
\hline \multirow[t]{2}{*}{ II. } & \multirow{2}{*}{$\begin{array}{l}\text { 1. metformin } \\
\text { 4. metformin + DPP- } 4 \mathrm{i}+\text { basal } \\
\text { insulin } \\
\text { 5. metformin + biphasic insulin }\end{array}$} & 6 months & $\begin{array}{c}2,844 \\
(3.13 \%) \\
\end{array}$ & $\begin{array}{c}8,012 \\
(41.31 \%) \\
\end{array}$ & $\begin{array}{c}-235 \\
(-3.18 \%) \\
\end{array}$ & $\begin{array}{c}-74 \\
(-2.73 \%) \\
\end{array}$ & \begin{tabular}{|c|}
-579 \\
$(-13.82 \%)$ \\
\end{tabular} & $\begin{array}{c}-1,286 \\
(-23.96 \%) \\
\end{array}$ & $\begin{array}{c}-27 \\
(-22.69 \%) \\
\end{array}$ & $\begin{array}{c}-214 \\
(-0.99 \%) \\
\end{array}$ \\
\hline & & 12 months & $\begin{array}{c}29,190 \\
(48.89 \%)\end{array}$ & $\begin{array}{c}12,077 \\
(102.71 \%)\end{array}$ & $\begin{array}{c}-848 \\
(-10.18 \%) \\
\end{array}$ & $\begin{array}{c}-285 \\
(-9.40 \%) \\
\end{array}$ & $\begin{array}{c}-2,631 \\
(-36.15 \%) \\
\end{array}$ & $\begin{array}{c}-9,753 \\
(-59.48 \%) \\
\end{array}$ & $\begin{array}{c}-209 \\
(-59.54 \%) \\
\end{array}$ & $\begin{array}{c}-1,404 \\
(-6.05 \%) \\
\end{array}$ \\
\hline \multirow[t]{3}{*}{ III. } & \multirow{2}{*}{$\begin{array}{l}\text { 4. metformin + DPP-4i+ basal } \\
\text { insulin } \\
\text { 5. metformin + biphasic insulin }\end{array}$} & 6 months & $\begin{array}{c}4,359 \\
(4.80 \%) \\
\end{array}$ & $\begin{array}{c}14,900 \\
(76.83 \%)\end{array}$ & $\begin{array}{c}-381 \\
(-5.16 \%) \\
\end{array}$ & $\begin{array}{c}-115 \\
(-4.24 \%) \\
\end{array}$ & $\begin{array}{c}-949 \\
(-22.65 \%) \\
\end{array}$ & $\begin{array}{c}-1,968 \\
(-36.66 \%)\end{array}$ & $\begin{array}{c}-40 \\
(-33.61 \%)\end{array}$ & $\begin{array}{c}-324 \\
(-1.50 \%) \\
\end{array}$ \\
\hline & & 12 months & $\begin{array}{c}33,586 \\
(56.26 \%) \\
\end{array}$ & $\begin{array}{c}21,768 \\
(185.13 \%) \\
\end{array}$ & $\begin{array}{c}-1,183 \\
(-14.20 \%) \\
\end{array}$ & $\begin{array}{c}-391 \\
(-12.90 \%) \\
\end{array}$ & $\begin{array}{c}-3,608 \\
(-49.57 \%) \\
\end{array}$ & $\begin{array}{c}-12,115 \\
(-73.89 \%) \\
\end{array}$ & $\begin{array}{c}-257 \\
(-73.22 \%) \\
\end{array}$ & $\begin{array}{c}-1,765 \\
(-7.61 \%) \\
\end{array}$ \\
\hline & Approach 2: Single-Stage Insulin & \multicolumn{9}{|c|}{ Incremental to Base Case } \\
\hline \multirow[t]{2}{*}{ IV. } & \multirow{2}{*}{$\begin{array}{l}\text { 1. metformin } \\
\text { 2. metformin + sulfonylurea } \\
\text { 3. metformin + sulfonylurea } \\
\text { + DPP- } 4 \mathrm{i} \\
\text { 5. metformin + biphasic insulin }\end{array}$} & 6 months & $\begin{array}{c}1,136 \\
(1.25 \%) \\
\end{array}$ & $\begin{array}{c}1,595 \\
(8.22 \%) \\
\end{array}$ & $\begin{array}{c}-101 \\
(-1.37 \%) \\
\end{array}$ & $\begin{array}{c}-33 \\
(-1.22 \%) \\
\end{array}$ & $\begin{array}{c}-212 \\
(-5.06 \%) \\
\end{array}$ & $\begin{array}{c}-490 \\
(-9.13 \%) \\
\end{array}$ & $\begin{array}{c}-13 \\
(-10.92 \%) \\
\end{array}$ & $\begin{array}{c}-85 \\
(-0.39 \%) \\
\end{array}$ \\
\hline & & 12 months & $\begin{array}{c}17,918 \\
(30.01 \%)\end{array}$ & $\begin{array}{c}1,752 \\
(14.90 \%)\end{array}$ & $\begin{array}{c}-299 \\
(-3.59 \%)\end{array}$ & $\begin{array}{c}-95 \\
(-3.13 \%)\end{array}$ & $\begin{array}{c}-909 \\
(-12.49 \%)\end{array}$ & $\begin{array}{c}-4,041 \\
(-24.65 \%)\end{array}$ & $\begin{array}{c}-93 \\
(-26.50 \%)\end{array}$ & $\begin{array}{c}-587 \\
(-2.53 \%)\end{array}$ \\
\hline \multirow[t]{2}{*}{$\overline{\mathrm{V}}$. } & \multirow{2}{*}{$\begin{array}{l}\text { 1. } \text { metformin } \\
\text { 2. metformin + sulfonylurea } \\
\text { 5. metformin + biphasic insulin }\end{array}$} & 6 months & $\begin{array}{c}2,272 \\
(2.50 \%) \\
\end{array}$ & $\begin{array}{c}5,630 \\
(29.03 \%) \\
\end{array}$ & $\begin{array}{c}-193 \\
(-2.61 \%) \\
\end{array}$ & $\begin{array}{c}-66 \\
(-2.43 \%) \\
\end{array}$ & $\begin{array}{c}-455 \\
(-10.86 \%) \\
\end{array}$ & $\begin{array}{c}-989 \\
(-18.42 \%) \\
\end{array}$ & $\begin{array}{c}-21 \\
(-17.65 \%)\end{array}$ & $\begin{array}{c}-173 \\
(-0.80 \%) \\
\end{array}$ \\
\hline & & 12 months & $\begin{array}{c}27,277 \\
(45.69 \%) \\
\end{array}$ & $\begin{array}{c}7,470 \\
(63.53 \%) \\
\end{array}$ & $\begin{array}{c}-674 \\
(-8.09 \%) \\
\end{array}$ & $\begin{array}{c}-232 \\
(-7.65 \%) \\
\end{array}$ & $\begin{array}{c}-2,075 \\
(-28.51 \%) \\
\end{array}$ & $\begin{array}{c}-8,189 \\
(-49.95 \%)\end{array}$ & $\begin{array}{c}-175 \\
(-49.86 \%)\end{array}$ & $\begin{array}{c}-1,180 \\
(-5.09 \%) \\
\end{array}$ \\
\hline \multirow[t]{2}{*}{ VI. } & \multirow[t]{2}{*}{$\begin{array}{l}\text { 1. metformin } \\
\text { 5. metformin + biphasic insulin }\end{array}$} & 6 months & $\begin{array}{c}4,004 \\
(4.41 \%)\end{array}$ & $\begin{array}{c}9,835 \\
(50.71 \%) \\
\end{array}$ & $\begin{array}{c}-363 \\
(-4.92 \%) \\
\end{array}$ & $\begin{array}{c}-105 \\
(-3.87 \%)\end{array}$ & $\begin{array}{c}-853 \\
(-20.36 \%) \\
\end{array}$ & $\begin{array}{c}-1,782 \\
(-33.20 \%)\end{array}$ & $\begin{array}{c}-36 \\
(-30.25 \%)\end{array}$ & $\begin{array}{c}-301 \\
(-1.39 \%) \\
\end{array}$ \\
\hline & & 12 months & $\begin{array}{c}32,864 \\
(55.05 \%)\end{array}$ & $\begin{array}{c}14,501 \\
(123.33 \%)\end{array}$ & $\begin{array}{c}-1,115 \\
(-13.38 \%) \\
\end{array}$ & $\begin{array}{c}-371 \\
(-12.24 \%)\end{array}$ & $\begin{array}{c}-3,384 \\
(-46.50 \%) \\
\end{array}$ & $\begin{array}{l}-11,672 \\
(-71.19 \%)\end{array}$ & $\begin{array}{c}-245 \\
(-69.80 \%) \\
\end{array}$ & $\begin{array}{l}-1,700 \\
(-7.33 \%)\end{array}$ \\
\hline \multirow[t]{2}{*}{ VII. } & \multirow[t]{2}{*}{ 5. metformin + biphasic insulin } & 6 months & $\begin{array}{l}5,585 \\
(6.15 \%) \\
\end{array}$ & $\begin{array}{c}17,032 \\
(87.82 \%)\end{array}$ & $\begin{array}{c}-510 \\
(-6.91 \%) \\
\end{array}$ & $\begin{array}{c}-145 \\
(-5.34 \%)\end{array}$ & $\begin{array}{c}-1,265 \\
(-30.19 \%) \\
\end{array}$ & $\begin{array}{c}-2,479 \\
(-46.18 \%) \\
\end{array}$ & $\begin{array}{c}-50 \\
(-42.02 \%) \\
\end{array}$ & $\begin{array}{c}-417 \\
(-1.93 \%) \\
\end{array}$ \\
\hline & & 12 months & $\begin{array}{l}36,675 \\
(61.43 \%)\end{array}$ & $\begin{array}{c}24,668 \\
(209.80 \%)\end{array}$ & $\begin{array}{c}-1,462 \\
(-17.54 \%)\end{array}$ & $\begin{array}{c}-464 \\
(-15.30 \%)\end{array}$ & $\begin{array}{c}-4,353 \\
(-59.81 \%) \\
\end{array}$ & $\begin{array}{c}-13,507 \\
(-82.38 \%)\end{array}$ & $\begin{array}{c}-282 \\
(-80.34 \%)\end{array}$ & $\begin{array}{l}-1,990 \\
(-8.58 \%)\end{array}$ \\
\hline
\end{tabular}

aResults presented as difference between SOC (steps 1,2,3,4,5) and each comparator strategy per 100,000 patients over a 5-year period. The percentages given represent the relative increase/decrease from the associated base case value.

$A 1 c=$ hemoglobin Alc; DPP-4i = dipeptidyl peptidase 4 inhibitor; ESRD = end-stage renal disease; $L E A=$ lower extremity amputation; MI = myocardial infarction;

SOC = standard of care; T2DM = type 2 diabetes mellitus.

\section{Discussion}

The ADA-EASD ${ }^{1}$ and the earlier AACE-ACE treatment guidelines ${ }^{17}$ suggest that the initial treatment with insulin of T2DM patients with high Alc levels at diagnosis is a viable care option. Our analysis looked at the clinical and cost outcomes of that option, as well as the earlier use of insulin within ADA-EASD guidelines. ${ }^{1}$ Treatment costs, efficacy, and estimated Alc drift for all treatments referenced in this study may be found in Appendix A. The costs of third-line noninsulin antidiabetics (e.g., DPP-4is, also GLP-1s and TZDs [not modeled]) are approaching and in some cases exceeding that for analog insulin treatments. Furthermore, these treatments lack insulin's efficacy, are subject to Alc drift, and do not have insulin's ability to have the dose precisely tailored. These factors motivated our interest in analyzing the outcomes of using insulin therapies earlier in T2DM treatment. 
FIGURE 3 Alc Levels of SOC and Strategies in Approach 1 and Approach 2 with Minimum Time on a Treatment of 6 and 12 Months

A. Approach 1: 6 Months

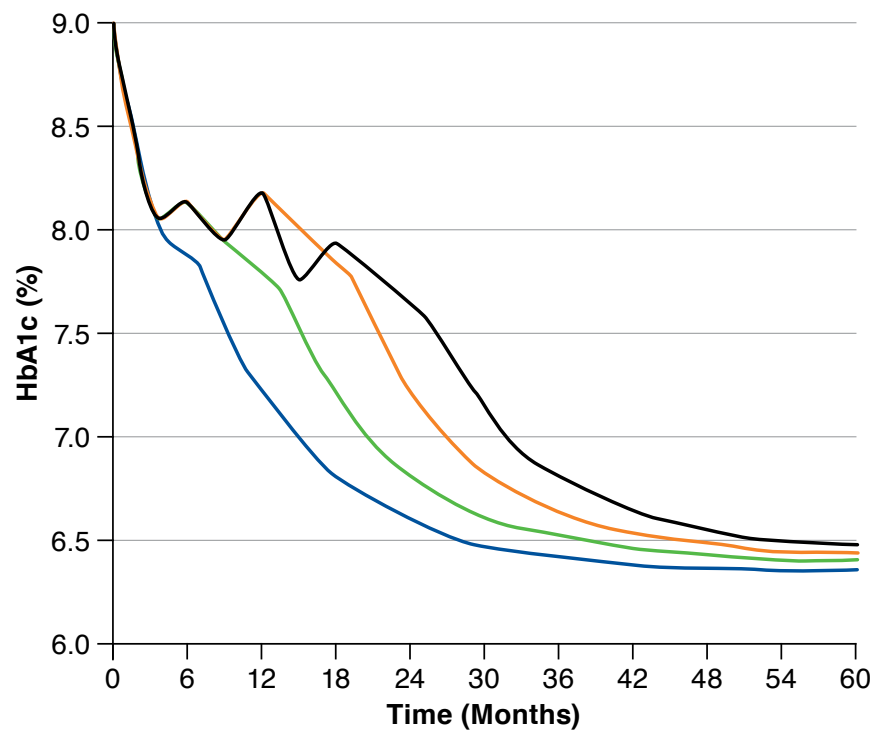

\begin{tabular}{ll}
\hline SOC & Steps $1,2,4,5$ \\
Steps $1,4,5$ & Steps 4,5
\end{tabular}

C. Approach 1: 12 Months

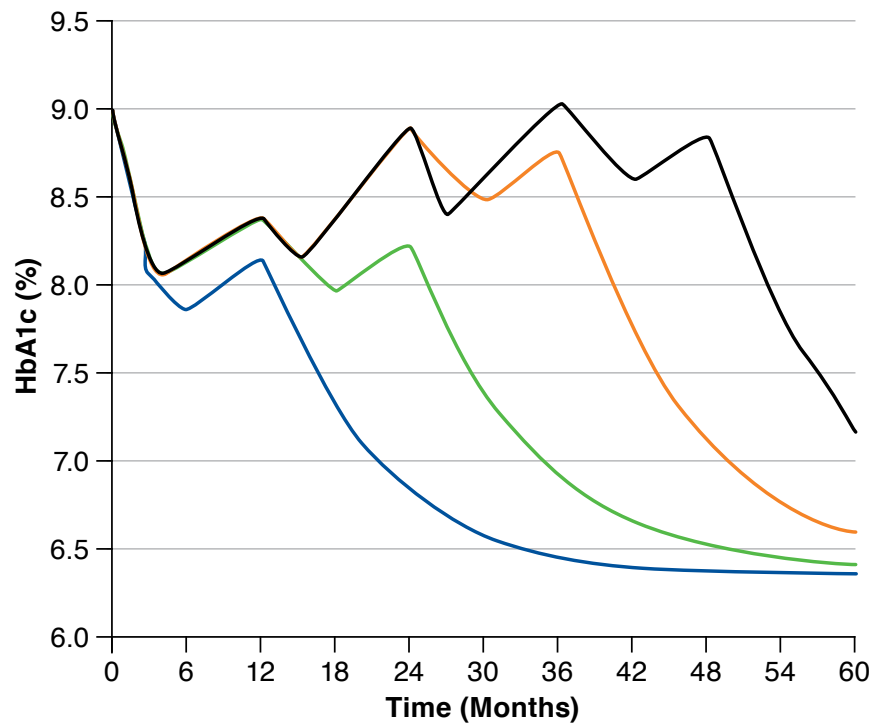

\begin{tabular}{|ll}
\hline SOC & Steps $1,2,4,5$ \\
Steps $1,4,5$ & Steps 4,5
\end{tabular}

B. Approach 2: 6 Months

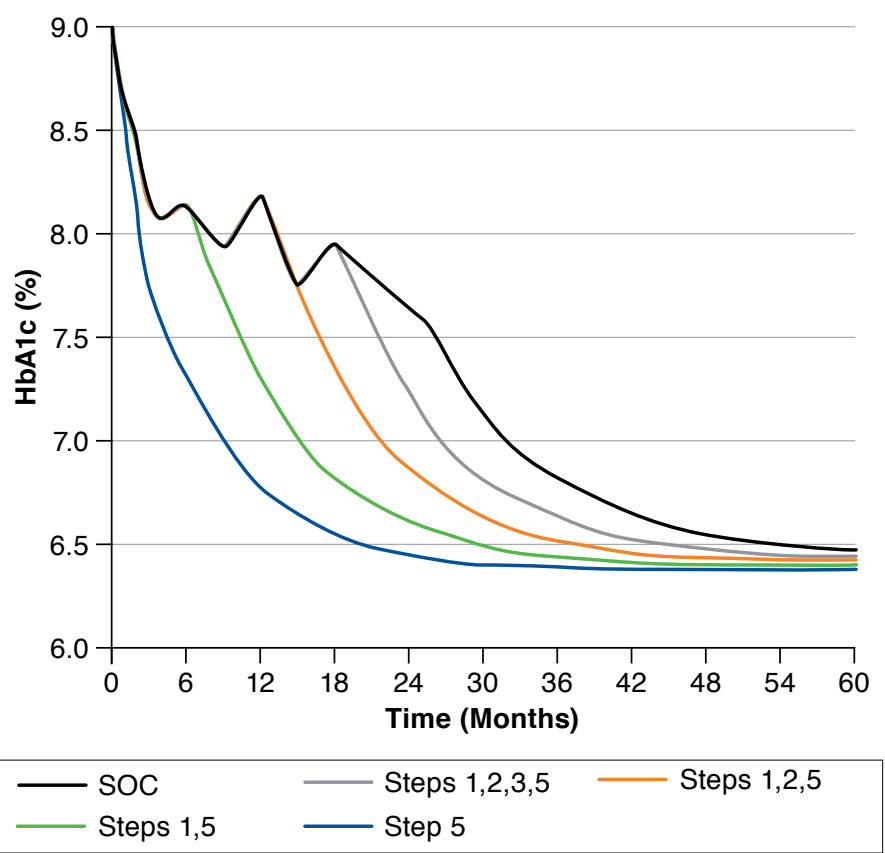

D. Approach 2: 12 Months

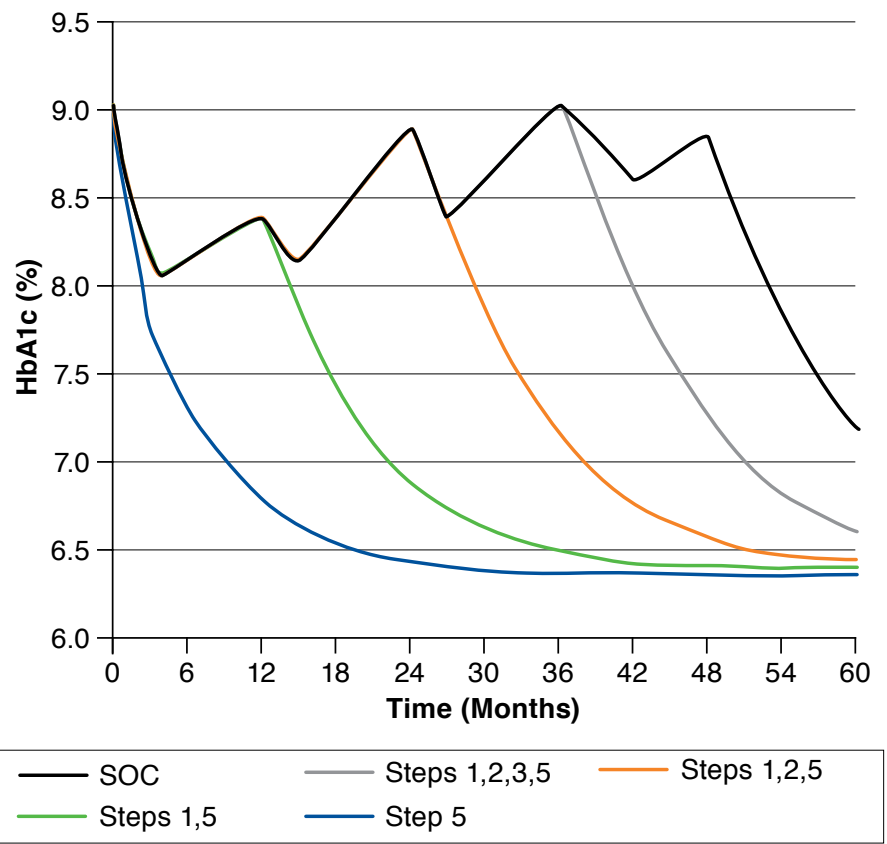

HbA1c=hemoglobin A1c; SOC= standard of care. 
Our results indicate that earlier use of insulin in patients with T2DM may provide significant clinical benefits through reductions in nonhypoglycemic major complications compared with the SOC treatment pattern examined. In some cases, by reducing such complications, the earlier use of insulin can save total costs in a 5-year period.

We selected well-documented studies with relatively similar trial populations across treatments to estimate treatment efficacy. Our choice of biphasic analog insulin as the basalbolus treatment was based on data from Holman et al. ${ }^{12}$ Other options, such as using basal and bolus insulin requiring separate injections ${ }^{37}$ or use of a pump, are viable but not included in this analysis. The primary reason for the selection of data from Suh et al., ${ }^{28}$ Rajagopalan et al., ${ }^{29}$ and Curkendall et al. ${ }^{22}$ was their use of large data sets (respectively, NHANES, Pharmetrics Patient Centric Database, and Thomson Reuters MarketScan) to generate estimates for critical parameters to our model.

We elected to use the 2007 Holman et al. study for the efficacy of metformin + biphasic insulin even though the vast majority of patients (over 90\%) in the study used metformin + sulfonylurea + biphasic insulin. This decision was made for several reasons: (a) the Holman et al. study presented results for 1 year, providing a longer period to identify any potential for treatment-related Alc drift, which is considered a critical issue in our study; (b) the duration of diabetes in Holman et al. was 9 years, so the efficacy of sulfonylurea (or metformin) except for new users would have waned (and would have been countered with up titrated insulin); and (c) the length of the Holman et al. study allowed for time to titrate insulin dosage providing for a better estimation of insulin use.

We opted to use insulin studies where dosage was titrated, since rapid and controllable titration is a valuable benefit of insulin use. We elected not to use insulin studies with starting Alc levels higher than 9.0. The insulin studies we reviewed generally showed a higher efficacy in lowering Alc as the starting Alc level rose (see, for example, Kahn et al. $2006^{9}$ or Kvapil et al. $2006^{38}$ ).

We used the minimum time on treatment as a proxy to estimate the impact of (patient and physician) controllable delays in escalating treatment of T2DM. Our results demonstrate that even a 3-month delay (from 3 to 6 months) in escalating treatment changes can have substantial clinical impact. Previous studies have suggested that these delays on any specific treatment can be as much as 3 years. ${ }^{36}$ Our results indicate that the importance of reducing delays in modifying or changing treatments for T2DM patients is at least as important as treatment efficacy in improving patient outcomes. Insulin use is not subject to the eventual loss of effectiveness and subsequent Alc drift associated with other treatments and, hence, is less affected by these delays.

The number of patients reaching the target Alc level of $<7 \%$ over 5 years is important, but the time required for these patients to reach the target is equally critical to their accumulated risk for having major nonhypoglycemic diabetic complications. Reaching the target earlier substantially lessens the occurrence of these complications.

Subsequent to this analysis, the AACE released its most recent diabetic management algorithm. ${ }^{39}$ The AACE treatment algorithm contains several differences to the ADA/EASD guidelines, most notably (with respect to the base case scenario evaluated here) the place and use of sulfonylureas in treatment. Regardless of which set of treatment recommendations or specific strategies are evaluated, the effects of Alc drift and the timing of treatment escalation affect clinical outcomes. The decision not to use a sulfonylurea after metformin would increase SOC costs as well as improve the clinical results for SOC for the base case.

Caution should be exercised when generalizing these results. We recognize that barriers to insulin use exist, which include cost, poor compliance with proper glucose monitoring, and aversion to self-injection. ${ }^{40,41}$ For example, a patient not comfortable with insulin injections and/or maintaining a pattern of glucose self-monitoring would likely not be a good candidate for insulin use until it is clinically required. Patients unwilling or unable to work regularly with a treating physician to modify dosing as required might also not benefit from more immediate insulin therapy.

\section{Limitations}

As with all models, our model is an approximation of the real system and should serve as a supplement to, and not a replacement for, the knowledge of established relevant experts. Our model was based on large, long-term studies with designs reflective of the current standards of care. Study length of at least 24 weeks was especially important in the estimation of Alc drift for noninsulin treatments and the quantity of insulin used. We chose not to estimate efficacy based on a meta-analysis because a review of the literature found only a handful of studies with adequate length and similarity in baseline patient Alc levels across treatments. Such an approach always carries the risk of publication bias-that is, only studies with positive results of newer treatments are published and indeterminate or negative results are not published.

Our analysis did not account for every cost or clinical factor. The value of reduced mortality (end of life cost) or estimated added life years was not included in the model. We did not estimate a cost or savings associated with weight gain or loss on a specific treatment. Clinical benefits in the model were expressed in terms of complications and mortality. Our analysis did not apply any utility metric (e.g., quality adjusted life years) to patient events or outcomes. 


\section{Conclusions}

Our analysis suggests that earlier insulin use has favorable clinical benefits and may reduce costs in specific cases. Our results also show that delays in making treatment changes as soon as indicated from patient Alc levels have significant clinical consequences. The earlier use of insulin will substantially reduce these consequences because it has very little or no Alc drift when properly titrated. The favorable profile we estimate from using insulin earlier in treatment can only be achieved for patients who can adapt to the discipline required by its use. As pointed out in both the ADA-EASD ${ }^{1}$ and AACE-ACE ${ }^{17}$ treatment guidelines, that determination requires thoughtful engagement by both the treating physician and the patient.

\section{REFERENCES}

1. Inzucchi SE, Bergenstal RM, Buse JB, et al. Management of hyperglycemia in type 2 diabetes: a patient-centered approach: position statement of the American Diabetes Association (ADA) and the European Association for the Study of Diabetes (EASD). Diabetes Care. 2012;35(6):1364-79.

2. Stratton IM, Adler AI, Neil HAW, et al. Association of glycaemia with macrovascular and microvascular complications of type 2 diabetes (UKPDS 35): prospective observational study. BMJ. 2000;321(7258):405-12.

3. ADVANCE Collaborative Group, Patel A, MacMahon S, et al. Intensive blood glucose control and vascular outcomes in patients with type 2 diabetes. N Engl J Med. 2008;358(24):2560-72. Available at: http://www.nejm.org/ doi/full/10.1056/NEJMoa0802987. Accessed June 23, 2014.

4. Turnbull FM, Abraira C, Anderson RJ, et al. Intensive glucose control and macrovascular outcomes in type 2 diabetes. Diabetologia. 2009;52(11):2288-98.

5. Nauck M, Frid A, Hermansen K, et al. Long-term efficacy and safety comparison of liraglutide, glimepiride and placebo, all in combination with metformin in type 2 diabetes: 2 -year results from the LEAD-2 study. Diabetes Obes Metab. 2013;15(3):204-12.

6. Hermansen K, Kipnes M, Luo E, et al. Efficacy and safety of the dipeptidyl peptidase-4 inhibitor, sitagliptin, in patients with type 2 diabetes mellitus inadequately controlled on glimepiride alone or on glimepiride and metformin. Diabetes Obes Metab. 2007;9(5):733-45.

7. Russell-Jones D, Schmitz O, Sethi BK, et al. Liraglutide vs insulin glargine and placebo in combination with metformin and sulfonylurea therapy in type 2 diabetes mellitus (LEAD-5 met $+\mathrm{SU}$ ): a randomised controlled trial. Diabetologia. 2009;52(10):2046-55

8. Hollander P, Raslova K, Skjøth TV, Råstam J, Liutkus JF. Efficacy and safety of insulin detemir once daily in combination with sitagliptin and metformin: the TRANSITION randomized controlled trial. Diabetes Obes Metab. 2011;13(3):268-75.

9. Kahn SE, Haffner SM, Heise MA, et al. Glycemic durability of rosiglitazone, metformin, or glyburide monotherapy. N Engl J Med. 2006;355(23):2427-43.

10. CDC Diabetes Cost-effectiveness Group. Cost-effectiveness of intensive glycemic control, intensified hypertension control, and serum cholesterol level reduction for type 2 diabetes. JAMA. 2002;287(19):2542-51.

11. Murphy DR, Klein RW, Smolen LJ, Klein TM, Roberts SD. Using common random numbers in health care cost-effectiveness simulation modeling. Health Serv Res. 2013;48(4):1508-25.

12. Holman RR, Thorne KI, Farmer AJ, et al. Addition of biphasic, prandial, or basal insulin to oral therapy in type 2 diabetes. N Engl J Med. 2007;357(17):1716-30.

13. Ligthelm R, Mouritzen U, Lynggaard H, et al. Biphasic insulin aspart given thrice daily is as efficacious as a basal-bolus insulin regimen with four daily injections: a randomised open-label parallel group four months comparison in patients with type 2 diabetes. Exp Clin Endocrinol Diabetes. 2006;114(9):511-19 
14. Masuda H, Sakamoto M, Irie J, et al. Comparison of twice-daily injections of biphasic insulin lispro and basal-bolus therapy: glycaemic control and quality-of-life of insulin-naive type 2 diabetic patients. Diabetes Obes Metab. 2008;10(12):1261-65.

15. Miser W, Arakaki R, Jiang H, Scism-Bacon J, Anderson P, Fahrbach J. Randomized, open-label, parallel-group evaluations of basal-bolus therapy versus insulin lispro premixed therapy in patients with type 2 diabetes mellitus failing to achieve control with starter insulin treatment and continuing oral antihyperglycemic drugs: a noninferiority intensification substudy of the DURABLE trial. Clin Ther. 2010;32(5):896-908.

16. Dieuzeide G, Chuang LM, Almaghamsi A, Zilov A, Chen JW, LavallaGonzález FJ. Safety and effectiveness of biphasic insulin aspart 30 in people with type 2 diabetes switching from basal-bolus insulin regimens in the Alchieve study. Prim Care Diabetes. 2014;8(2):111-17.

17. Rodbard HW, Jellinger PS, Davidson JA, et al. Statement by an American Association of Clinical Endocrinologists/American College of Endocrinology consensus panel on type 2 diabetes mellitus: an algorithm for glycemic control. Endocr Pract. 2009;15(6):540-59.

18. U.S. Census Bureau. Current population survey (CPS). 2008. Updated June 2012. Available at: http://www.census.gov/cps/. Accessed June 23, 2014.

19. Centers for Disease Control and Prevention. National Health and Nutrition Examination Survey. Questionaires, datasets, and related documentation. NHANES 2009-2010. Available at: http://www.cdc.gov/nchs/ nhanes/nhanes_questionnaires.htm. Accessed June 23, 2014.

20. Danaei G, Friedman AB, Oza S, Murray CJ, Ezzati M. Diabetes prevalence and diagnosis in US states: analysis of health surveys. Popul Health Metr. 2009;7:16.

21. Valentine WJ, Palmer AJ, Nicklasson L, Cobden D, Roze S. Improving life expectancy and decreasing the incidence of complications associated with type 2 diabetes: a modelling study of HbAlc targets. Int J Clin Pract. 2006;60(9):1138-45.

22. Curkendall SM, Zhang B, Oh KS, Williams SA, Pollack MF. Incidence and cost of hypoglycemia among patients with type 2 diabetes in the United States: analysis of a health insurance database. JCOM. 2011;18(10):455-62. Available at: http://w.turner-white.com/pdf/jcom_octll_hypoglycemia.pdf. Accessed June 23, 2014.

23. Stevens RJ, Kothari V, Adler AI, Stratton IM; United Kingdom Prospective Diabetes Study (UKPDS) Group. The UKPDS risk engine: a model for the risk of coronary heart disease in type II diabetes (UKPDS 56). Clin Sci (Lond). 2001;101(6):671-79.

24. Ruggenenti P, Fassi A, Ilieva AP, et al. Preventing microalbuminuria in type 2 diabetes. N Engl J Med. 2004;351(19):1941-51.

25. UK Prospective Diabetes Study Group. Tight blood pressure control and risk of macrovascular and microvascular complications in type 2 diabetes: UKPDS 38. BMJ. 1998;317(7160):703-13.

26. Shepherd J, Cobbe SM, Ford I, et al. Prevention of coronary heart disease with pravastatin in men with hypercholesterolemia. West of Scotland Coronary Prevention Study Group. N Engl J Med. 1995;333(20):1301-07.
27. Goldberg RB, Mellies MJ, Sacks FM, et al. Cardiovascular events and their reduction with pravastatin in diabetic and glucose-intolerant myocardial infarction survivors with average cholesterol levels: subgroup analyses in the Cholesterol And Recurrent Events (CARE) Trial. Circulation. 1998;98(23):2513-19.

28. Suh DC, Choi IS, Plauschinat C, Kwon J, Baron M. Impact of comorbid conditions and race/ethnicity on glycemic control among the US population with type 2 diabetes, 1988-1994 to 1999-2004. J Diabetes Complications. 2010;24(6):382-91.

29. Rajagopalan R, Joyce A, Ollendorf D, Murray FT. Medication compliance in type 2 diabetes subjects: retrospective data analysis. Value Health. 2003;6(3):328.

30. Brandle M, Zhou H, Smith BR, et al. The direct medical cost of type 2 diabetes. Diabetes Care. 2003;26(8):2300-04.

31. Red Book Online. Red Book Online Search. 2013. Available at: http:// www.micromedexsolutions.com/micromedex2/librarian/ND_T/evidencexpert/ND_PR/evidencexpert/CS/70DF80/ND_AppProduct/evidencexpert/ DUPLICATIONSHIELDSYNC/F5F122/ND_PG/evidencexpert/ND_B/ evidencexpert/ND_P/evidencexpert/PFActionId/redbook.FindRedBook. Accessed June 23, 2014.

32. U.S. Department of Labor. Bureau of Labor Statistics. Consumer Price Index-All Urban Consumers. U.S. Medical Care, 1982-84=100 - CUUR0000SAM. July 2013. Available at: http://data.bls.gov/cgi-bin/ surveymost?cu. Accessed June 23, 2014.

33. Brown JB, Nichols GA, Perry A. The burden of treatment failure in type 2 diabetes. Diabetes Care. 2004;27(7):1535-40.

34. Calvert MJ, McManus RJ, Freemantle N. Management of type 2 diabetes with multiple oral hypoglycaemic agents or insulin in primary care: retrospective cohort study. Br J Gen Pract. 2007;57(539):455-60.

35. Grant RW, Buse JB, Meigs JB; University HealthSystem Consortium (UHC) Diabetes Benchmarking Project Team. Quality of diabetes care in U.S. academic medical centers: low rates of medical regimen change. Diabetes Care. 2005;28(2):337-442.

36. Nichols GA, Koo YH, Shah SN. Delay of insulin addition to oral combination therapy despite inadequate glycemic control: delay of insulin therapy. J Gen Intern Med. 2007;22(4):453-58.

37. Fritsche A, Larbig M, Owens D, Häring H-U; GINGER study group. Comparison between a basal-bolus and a premixed insulin regimen in individuals with type 2 diabetes: results of the GINGER study. Diabetes Obes Metab. 2010;12(2):115-23.

38. Kvapil M, Swatko A, Hilberg C, Shestakova M. Biphasic insulin aspart 30 plus metformin: an effective combination in type 2 diabetes. Diabetes Obes Metab. 2006;8(1):39-48.

39. Garber AJ, Abrahamson MJ, Barzilay JI, et al. AACE comprehensive diabetes management algorithm 2013. Endocr Pract. 2013;19(2):327-35.

40. Peyrot M, Rubin RR, Lauritzen T, et al. Resistance to insulin therapy among patients and providers results of the cross-national Diabetes Attitudes, Wishes, and Needs (DAWN) study. Diabetes Care. 2005;28(11):2673-79. 
41. Karter AJ, Subramanian U, Saha C, et al. Barriers to insulin initiation: the translating research into action for diabetes insulin starts project. Diabetes Care. 2010;33(4):733-35.

42. Raz I, Wilson PWF, Strojek K, et al. Effects of prandial versus fasting glycemia on cardiovascular outcomes in type 2 diabetes: the HEART2D trial. Diabetes Care. 2009;32(3):381-86.

43. Powell CK, Hill EG, Clancy DE. The relationship between health literacy and diabetes knowledge and readiness to take health actions. Diabetes Educ. 2007;33(1):144-51.

44. Adams AS, Trinacty CM, Zhang F, et al. Medication adherence and racial dDifferences in Alc control. Diabetes Care. 2008;31(5):916-21.

45. UK Prospective Diabetes Study Group. Intensive blood-glucose control with sulphonylureas or insulin compared with conventional treatment and risk of complications in patients with type 2 diabetes (UKPDS 33). Lancet. 1998;352(9131):837-53.

46. American Diabetes Association. Treatment of hypertension in adults with diabetes. Diabetes Care. 2003;26(Suppl 1):580-82.
47. Du X, Ninomiya T, De Galan B, et al. Risks of cardiovascular events and effects of routine blood pressure lowering among patients with type 2 diabetes and atrial fibrillation: results of the ADVANCE study. Eur Heart J. 2009;30(9):1128-35.

48. Nauck MA, Ellis GC, Fleck PR, Wilson CA, Mekki Q; Alogliptin Study 008 Group. Efficacy and safety of adding the dipeptidyl peptidase-4 inhibitor alogliptin to metformin therapy in patients with type 2 diabetes inadequately controlled with metformin monotherapy: a multicentre, randomised, double-blind, placebo-controlled study. Int J Clin Pract. 2009;63(1):46-55.

49. Robbins DC, Beisswenger PJ, Ceriello A, et al. Mealtime 50/50 basal+ prandial insulin analogue mixture with a basal insulin analogue, both plus metformin, in the achievement of target HbAlc and pre- and postprandial blood glucose levels in patients with type 2 diabetes: a multinational, 24-week, randomized, open-label, parallel-group comparison. Clin Ther. 2007;29(11):2349-64

50. Buse JB, Bergenstal RM, Glass LC, et al. Use of twice-daily exenatide in basal insulin-treated patients with type 2 diabetes: a randomized, controlled trial. Ann Intern Med. 2011;154(2):103-12. 


\section{APPENDIX A Model Input Data}

Parameter

Value

References

Patient demographic data

Male (\%)

Age

Male

Female

Non-Hispanic white male

Non-Hispanic black male

Hispanic male

Other male

Non-Hispanic white female

Non-Hispanic black female

Hispanic female

Other female

Lifestyle and disease management (\%)

Smoker

Outpatient diabetes management training

Type 2 diabetes-related medications (\%)

Antihypertensive agents

ACE inhibitor

Statin (lipid-lowering agents)

Cohort Alc

Target Alc

Alc at diagnosis

Non-Hispanic white

Non-Hispanic black

Hispanic

Other

Clinical data

Systolic blood pressure $(\mathrm{mmHg})$

Total cholesterol (mg/dL)

High-density lipoprotein (mg/dL)

Body mass index $\left(\mathrm{kg} / \mathrm{m}^{2}\right)$

Hypertensive (\%)

Cohort initial diabetic-related complications (\%)

Retinopathy

No retinopathy

Photo coagulation

Blind

Nephropathy

No nephropathy

Microalbuminuria

Clinical nephropathy

End-stage renal disease

Neuropathy

No neuropathy

Peripheral neuropathy

LEA

Coronary heart disease

No CHD

Angina

History of MI/CA

Stroke

No stroke

History of stroke

Atrial fibrillation

16

$$
\leq 7.0 \%
$$

\begin{tabular}{|c|c|}
\hline Mean $(\%)$ & \\
\hline 8.9 & \\
9.8 & \\
9.8 & \\
9.9 & \\
\hline Mean & \\
\hline 135 & \\
\hline 209 & \\
\hline 41 & \\
\hline 32 &
\end{tabular}

Minimum (\%)

6.5

6.5

6.5

6.5

Minimum

110

110

120
25

20

40

91
9
0

92

\begin{tabular}{|c|c}
\hline & 92 \\
4 \\
4 \\
4 \\
0
\end{tabular}

0

76

23

1

87

2

11

91

9

7.6
49

40-64 (\%)

20-39 (\%)

\begin{tabular}{|c|c|c|}
\hline \multicolumn{3}{|c|}{49} \\
\hline $20-39(\%)$ & $40-64(\%)$ & $\geq 65(\%)$ \\
\hline 8 & 57 & 35 \\
\hline 58 & 53 & 70 \\
\hline 16 & 68 & 11 \\
\hline 21 & 14 & 9 \\
\hline 5 & 14 & 3 \\
\hline 18 & 4 & 75 \\
\hline 19 & 66 & 13 \\
\hline 5 & 16 & 9 \\
\hline
\end{tabular}

19,20

42

43

\begin{tabular}{|c|c}
51 & 9 \\
\hline 41 & 21 \\
\hline 45 & 21
\end{tabular}

9

21

User input

28,44

17.0

17.0

17.1

Maximum

190

400

80

50

21

46

47 


\section{APPENDIX A Model Input Data (continued)}

\begin{tabular}{|c|c|c|c|c|c|c|}
\hline \multicolumn{2}{|l|}{ Parameter } & \multicolumn{4}{|c|}{ Value } & \multirow[t]{2}{*}{ References } \\
\hline \multicolumn{6}{|l|}{ Treatment effectiveness } & \\
\hline \multicolumn{2}{|l|}{ Treatment } & $\begin{array}{c}\text { Efficacy } \\
\text { (\% per Month) }\end{array}$ & $\begin{array}{l}\text { Months Until } \\
\text { Drift Starts }\end{array}$ & $\begin{array}{c}\text { Drift Rate } \\
\text { (Absolute \% per } \\
\text { Month) }\end{array}$ & $\begin{array}{c}\text { Annual Probability } \\
\text { of Severe } \\
\text { Hypoglycemia (\%) }\end{array}$ & \\
\hline \multicolumn{2}{|l|}{ Metformin } & 1.86 & 4 & 0.0231 & 0.300 & 5,22 \\
\hline \multicolumn{2}{|l|}{ Metformin + sulfonylurea } & 1.96 & 3 & 0.1036 & 0.896 & 7,22 \\
\hline \multicolumn{2}{|l|}{ Metformin + DPP-4i } & 2.93 & 3 & 0.0200 & 1.862 & 22,48 \\
\hline \multicolumn{2}{|l|}{ Metformin + GLP-1 RA } & 4.81 & 4 & 0.0271 & 1.862 & 5,22 \\
\hline \multicolumn{2}{|l|}{ Metformin + basal insulin } & 1.45 & $6^{a}$ & $0.0245^{a}$ & 6.303 & $22,49,12^{\mathrm{a}}$ \\
\hline \multicolumn{2}{|c|}{ Metformin + sulfonylurea + DPP- $4 \mathrm{i}$} & 3.60 & 3 & 0.0804 & 1.862 & 6,22 \\
\hline \multicolumn{2}{|c|}{ Metformin + sulfonylurea + GLP-1 RA } & 4.94 & 4 & 0.1367 & 3.921 & 7,22 \\
\hline \multicolumn{2}{|c|}{ Metformin + sulfonylurea + basal insulin } & 3.68 & 4 & 0.0546 & 7.263 & 7,22 \\
\hline \multicolumn{2}{|c|}{ Metformin + DPP-4i+basal insulin } & 2.65 & 6 & $0.0200^{\mathrm{b}}$ & 6.303 & $8,22,48^{b}$ \\
\hline \multicolumn{2}{|c|}{ Metformin + GLP-1 RA+ basal insulin } & 5.71 & 4 & 0.0318 & 6.303 & 22,50 \\
\hline Metformin + biphasic inst & & 5.32 & $1,000^{\mathrm{c}}$ & 0.0 & 8.790 & 12,22 \\
\hline Metformin + basal + bolus & ssulin & 5.55 & $1,000^{c}$ & 0.0 & 8.790 & 22,37 \\
\hline Treatment adherence and & abetes manageme & and control & & & & \\
\hline Probability adherent & & $\begin{array}{l}\text { Non-Hispanic } \\
\text { White (\%) }\end{array}$ & $\begin{array}{c}\text { Non-Hispanic } \\
\text { Black (\%) }\end{array}$ & $\begin{array}{l}\text { Hispanic } \\
(\%)\end{array}$ & $\begin{array}{c}\text { Other } \\
(\%)\end{array}$ & 28,29 \\
\hline Any OAD & & 81 & 58 & 58 & 54 & \\
\hline Any insulin & & 62 & 45 & 45 & 42 & \\
\hline Patients with durability a & er reaching target & 46 & 33 & 33 & 31 & 28 \\
\hline Multiplicative complicatio & costs & & & & & \\
\hline Annual direct medical cost & (per patients) & & & & & 30 \\
\hline Cost multipliers & & & & & & \\
\hline Female & & & & & & \\
\hline BMI [=input^(BMI-30)] & & & & & & \\
\hline Antihypertensive agents & & & & & & \\
\hline Microalbuminuria & & & & & & \\
\hline Proteinuria & & & & & & \\
\hline End-stage renal disease & & & & & & \\
\hline Treatment of stroke & & & & & & \\
\hline Treatment of angina & & & & & & \\
\hline History of MI & & & & & & \\
\hline Peripheral vascular disease & & & & & & \\
\hline Annual costs (per patients & & & & & & \\
\hline Antidiabetes agents & Active Ingr & dient, Drug Name & $\begin{array}{l}\text { Dc } \\
\text { (Un }\end{array}$ & & nnual Cost (\$) & \\
\hline Metformin & Metfor & in, Metformin & & & 72 & 31 (WACs) \\
\hline Sulfonylurea & Gly & uride, Teva & & & 100 & \\
\hline DPP- $4 \mathrm{i}$ & Sitagliptin & hosphate, Januvia & & & 2,992 & \\
\hline GLP-1 RA & Exel & tide, Byetta & & & 5,979 & \\
\hline Basal insulin & Insulin deten & r, (Levemir FlexPen) & & & 3,338 & \\
\hline Biphasic insulin & $\begin{array}{r}\text { Insulin Aspart/I } \\
\text { (Novolog }\end{array}$ & $\begin{array}{l}\text { sulin Aspart Protamine } \\
\text { ix } 70 / 30 \text { FlexPen) }\end{array}$ & & & 3,452 & \\
\hline Basal+bolus insulin & $\begin{array}{r}\text { Insulin glargine } \\
\text { solostar }\end{array}$ & $\begin{array}{l}\text { nsulin glulisine, (Lantu } \\
\text { apidra solostar) }\end{array}$ & & & 6,068 & \\
\hline
\end{tabular}




\section{APPENDIX A Model Input Data (continued)}

\begin{tabular}{|c|c|c|}
\hline Parameter & Value & References \\
\hline \multicolumn{2}{|l|}{ Event costs } & \multirow[t]{4}{*}{30} \\
\hline Acute stroke event cost & $\$ 42,907$ & \\
\hline Acute MI/CA event cost & $\$ 39,520$ & \\
\hline Acute LEA event cost & $\$ 60,651$ & \\
\hline \multicolumn{3}{|l|}{ Adverse event costs } \\
\hline Severe hypoglycemia & $\$ 1,165$ & 22 \\
\hline Weight gain (at least $5 \mathrm{~kg}$ ) & $\$ 0$ & \\
\hline \multicolumn{3}{|l|}{ Alc and treatment-related relative risks } \\
\hline \multicolumn{3}{|l|}{ Retinopathy } \\
\hline Alc-related relative risk & $37 \%$ decrease per $1 \%$ reduction in Alc & 2 \\
\hline \multicolumn{3}{|l|}{ Nephropathy } \\
\hline Hypertension treatment relative risk & $52 \%$ if on an ACE inhibitor & 24 \\
\hline Alc-related relative risk & $37 \%$ decrease per $1 \%$ reduction in Alc & 2 \\
\hline \multicolumn{3}{|l|}{ Neuropathy } \\
\hline Alc-related relative risk (microvascular disease) & $37 \%$ decrease per $1 \%$ reduction in Alc & 2 \\
\hline Alc-related relative risk (peripheral vascular disease) & $43 \%$ decrease per $1 \%$ reduction in Alc & 2 \\
\hline \multicolumn{3}{|l|}{ CHD } \\
\hline Cholesterol-controlled relative risk (first incidence of CHD) & $69 \%$ if on a statin & 26 \\
\hline Cholesterol-controlled relative risk (subsequent CHD) & $75 \%$ if on a statin & 27 \\
\hline Hypertension treatment relative risk & $79 \%$ if on antihypertensive agent & 25 \\
\hline Alc-related relative risk & $14 \%$ decrease per $1 \%$ reduction in $\mathrm{Alc}$ & 2 \\
\hline \multicolumn{3}{|l|}{ Stroke } \\
\hline Hypertension treatment relative risk & $56 \%$ if on antihypertensive agent & 25 \\
\hline Alc-related relative risk & $12 \%$ decrease per $1 \%$ reduction in $\mathrm{Alc}$ & 2 \\
\hline
\end{tabular}

Alc-related relative risk

${ }^{b}$ Use metformin + DPP-4i data.

'No effective drift.

dDosage obtained from Hollander et al. 2011.8

eDosage obtained from Holman et al. 2007.12

fDosage obtained from Fritsche et al. 2010.37

$A C E$ inhibitor = angiotensin-converting enzyme inhibitor; Alc=hemoglobin Alc; BMI=body mass index; $C H D=$ coronary heart disease; DPP-4i=dipeptidyl peptidase 4 inhibitor; GLP-1 RA=glucagon-like peptide-1 receptor agonist; $\mathrm{kg}=$ kilogram; $\mathrm{kg} / \mathrm{m}^{2}=$ kilogram per square meter; $L E A=l o w e r$ extremity amputation; $\mathrm{mg} / \mathrm{dL}=$ milligram per deciliter; $\mathrm{MI} / \mathrm{CA}=$ myocardial infarction/cardiac arrest; $\mathrm{mm} \mathrm{Hg}=$ millimeter of mercury; $\mathrm{OAD}=$ oral antidiabetes drugs; WAC=wholesale acquisition cost. 


\section{APPENDIX B Cost Outcome Model Results: Total Costs, Pharmacy Costs, and Direct Medical Costs ${ }^{\mathrm{a}}$}

\begin{tabular}{|c|c|c|c|c|c|}
\hline \multicolumn{2}{|c|}{ Comparator Strategy } & $\begin{array}{l}\text { Minimum Time on } \\
\text { Treatment }\end{array}$ & $\begin{array}{c}\text { Pharmacy Costs } \\
\text { Per Patient }\end{array}$ & $\begin{array}{c}\text { Direct Medical Costs } \\
\text { Per Patient }\end{array}$ & $\begin{array}{l}\text { Total Costs } \\
\text { Per Patient }\end{array}$ \\
\hline & Standard of Care & \multicolumn{4}{|c|}{ Baseline } \\
\hline \multirow[t]{3}{*}{0.} & 1. metformin & 6 Months & $\$ 10,489$ & $\$ 26,216$ & $\$ 36,705$ \\
\hline & $\begin{array}{l}\text { 3. metformin }+ \text { sulfonylurea }+ \text { DPP- } 4 \mathrm{i} \\
\text { 4. metformin + DPP- } 4 \mathrm{i}+\text { basal insulin } \\
\text { 5. metformin + biphasic insulin }\end{array}$ & 12 Months & $\$ 8,352$ & $\$ 33,995$ & $\$ 42,347$ \\
\hline & Approach 1: Two-Stage Insulin & \multicolumn{4}{|c|}{ Incremental to Baseline } \\
\hline \multirow[t]{2}{*}{ I. } & \multirow{2}{*}{$\begin{array}{l}\text { 1. metformin } \\
\text { 2. metformin + sulfonylurea } \\
\text { 4. metformin + DPP-4i+basal insulin } \\
\text { 5. metformin + biphasic insulin }\end{array}$} & 6 Months & $\$ 176(1.68 \%)$ & $-\$ 312(-1.19 \%)$ & $-\$ 136(-0.37 \%)$ \\
\hline & & 12 Months & $\$ 462(5.53 \%)$ & $-\$ 3,122(-9.18 \%)$ & $-\$ 2,660(-6.28 \%)$ \\
\hline \multirow[t]{2}{*}{ II. } & \multirow{2}{*}{$\begin{array}{l}\text { 1. metformin } \\
\text { 4. metformin + DPP- } 4 i+\text { basal insulin } \\
\text { 5. metformin + biphasic insulin }\end{array}$} & 6 Months & $\$ 2,078(19.81 \%)$ & $-\$ 1,007(-3.84 \%)$ & $\$ 1,071(2.92 \%)$ \\
\hline & & 12 Months & $\$ 3,648(43.68 \%)$ & $-\$ 6,787(-19.96 \%)$ & $-\$ 3,139(-7.41 \%)$ \\
\hline \multirow[t]{3}{*}{ III. } & \multirow{2}{*}{$\begin{array}{l}\text { 4. metformin + DPP- } 4 i+\text { basal insulin } \\
\text { 5. metformin + biphasic insulin }\end{array}$} & 6 Months & $\$ 4,716(44.96 \%)$ & $-\$ 1,541(-5.88 \%)$ & $\$ 3,175(8.65 \%)$ \\
\hline & & 12 Months & $\$ 7,671(91.85 \%)$ & $-\$ 8,582(-25.24 \%)$ & $-\$ 912(-2.15 \%)$ \\
\hline & Approach 2: Single-Stage Insulin & \multicolumn{4}{|c|}{ Incremental to Baseline } \\
\hline \multirow[t]{2}{*}{ IV. } & \multirow{2}{*}{$\begin{array}{l}\text { 1. metformin } \\
\text { 2. metformin + sulfonylurea } \\
\text { 3. metformin + sulfonylurea + DPP- } 4 \mathrm{i} \\
\text { 5. metformin + biphasic insulin }\end{array}$} & 6 Months & $-\$ 1,654(-15.77 \%)$ & $-\$ 387(-1.48 \%)$ & $-\$ 2,041(-5.56 \%)$ \\
\hline & & 12 Months & $-\$ 1,798(-21.53 \%)$ & $-\$ 2,711(-7.97 \%)$ & $-\$ 4,509(-10.65 \%)$ \\
\hline \multirow[t]{2}{*}{ V. } & \multirow{2}{*}{$\begin{array}{l}\text { 1. metformin } \\
\text { 2. metformin + sulfonylurea } \\
\text { 5. metformin + biphasic insulin }\end{array}$} & 6 Months & $-\$ 1,550(-14.78 \%)$ & $-\$ 759(-2.90 \%)$ & $-\$ 2,309(-6.29 \%)$ \\
\hline & & 12 Months & $-\$ 1,635(-19.58 \%)$ & $-\$ 5,595(-16.46 \%)$ & $-\$ 7,230(-17.07 \%)$ \\
\hline \multirow[t]{2}{*}{ VI. } & \multirow{2}{*}{$\begin{array}{l}\text { 1. metformin } \\
\text { 5. metformin + biphasic insulin }\end{array}$} & 6 Months & $\$ 94(0.90 \%)$ & $-\$ 1,436(-5.48 \%)$ & $-\$ 1,342(-3.66 \%)$ \\
\hline & & 12 Months & $\$ 1,071(12.82 \%)$ & $-\$ 8,271(-24.33 \%)$ & $-\$ 7,200(-17.00 \%)$ \\
\hline \multirow[t]{2}{*}{ VII. } & \multirow[t]{2}{*}{ 5. metformin + biphasic insulin } & 6 Months & $\$ 2,569(24.49 \%)$ & $-\$ 2,007(-7.66 \%)$ & $\$ 562(1.53 \%)$ \\
\hline & & 12 Months & $\$ 4,706(56.35 \%)$ & $-\$ 9,786(-28.79 \%)$ & $-\$ 5,080(-12.00 \%)$ \\
\hline
\end{tabular}

a Results presented as difference between SOC (steps 1,2,3,4,5) and each comparator strategy per patient over a 5-year period. The percentages given represent the relative increase/decrease from the associated base case value.

DPP- $4 i=$ dipeptidyl peptidase 4 inhibitor; SOC = standard of care. 